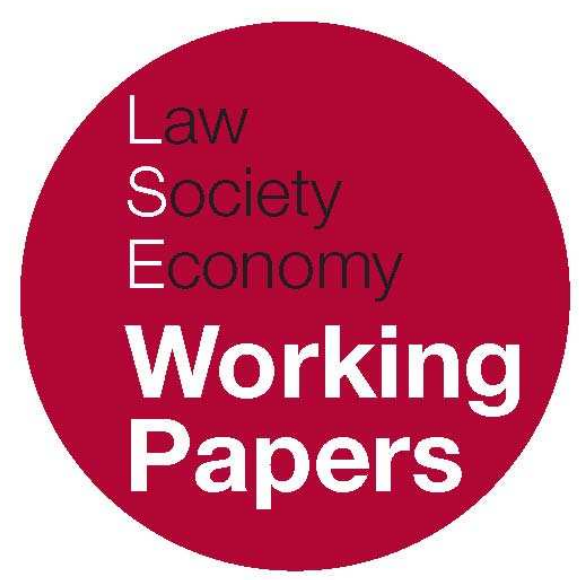

\title{
The Case for Pluralism in Postnational Law
}

Nico Krisch

LSE Law, Society and Economy Working Papers 12/2009

London School of Economics and Political Science

Law Department

This paper can be downloaded without charge from LSE Law, Society and Economy Working Papers at: www.lse.ac.uk/collections/law/wps/wps.htm and the Social Sciences Research Network electronic library at: http://ssrn.com/abstract=1418707.

(C) Nico Krisch. Users may download and/or print one copy to facilitate their private study or for non-commercial research. Users may not engage in further distribution of this material or use it for any profit-making activities or any other form of commercial gain. 


\title{
The Case for Pluralism in Postnational Law
}

\author{
Nico Krisch ${ }^{*}$
}

\begin{abstract}
As the divide between domestic and international law becomes blurred, paradigms for the structure of the new, postnational legal order remain elusive, on both the analytical and the normative plane. In this paper, I inquire into the normative status of two main candidates, constitutionalism and pluralism. The constitutionalist ideal of a coherent, hierarchically structured order in a framework defined by law is often seen as an attractive goal also for postnational politics, but on closer look it turns out to face similar problems as in domestic divided societies, especially with respect to power, integration and the rule of law. Pluralism, on the other hand, is often regarded as better suited to conditions of radical diversity as they prevail in the postnational realm. The openness of legal relations between different parts of a political order is seen to foster greater adaptability, responsiveness to contestation and an ability to steer a path between competing (and equally deficient) supremacy claims. Yet while these are important virtues, I argue that a defence of a pluralist postnational law has to find its starting point elsewhere: in the public autonomy of citizens in the definition of their legal and political framework. Such an approach shifts the focus to social attitudes and identities, to the multiplicity of loyalties and allegiances characteristic of the global polity. These do indeed appear to be better reflected in a pluralist than in a constitutionalist order.
\end{abstract}

\section{INTRODUCTION}

Times of transition are often more exciting than those of routine and continuity, but they are typically also disorderly and confusing. Old paradigms fade, but new ones only emerge slowly, and their multiplicity leads to protracted phases of

\footnotetext{
${ }^{*}$ Hertie School of Governance, Berlin; Visiting Fellow, Law Department, London School of Economics and Political Science; krisch@hertie-school.org. I am grateful to Nicolas Lamp, Richard Stewart, Chandran Kukathas, Neus Torbisco Casals and the participants in a workshop at NYU Law School, a colloquium at the LSE Law Department and a conference at Oxford University for comments and discussion on an earlier draft. A revised version of this paper will appear in G. de Burca \& J.H.H. Weiler (eds), The Worlds of European Constitutionalism (Cambridge: Cambridge University Press, forthcoming).
} 
coexistence, competition and conflict. The current 'disorder of orders' 1 in the conceptualisation of postnational law is a signal of such a transition and an indication of its depth. The 'Westphalian' system, with its clear separation between domestic and international levels of law and only relatively thin forms of coordination and cooperation in the latter, has broken down under the weight of Europeanisation and globalisation, but its successor has not been appointed yet. Several candidates are in the race $^{2}$, and one main dividing line - the one this paper focuses on - is between constitutionalist and pluralist approaches to postnational order. Both of these come in many guises, but they typically differ in their understanding of central structural traits of the legal and political order. While constitutionalists, drawing on domestic inspirations, generally strive for a common frame to define both the substantive principles of the overall order and the relations between its different parts, pluralists prefer to see the postnational realm as characterised by heterarchy, by an interaction of different sub-orders that is not subject to common legal rules but takes a more open, political form.

This contrast may seem overdrawn; perhaps one should steer a less conflictive path and work towards reconciling these two visions in some form of 'constitutional pluralism'. ${ }^{3}$ But such a conciliatory move would conceal, rather than bring into relief, the theoretical and practical differences that exist between constitutionalist, unity-oriented, and pluralist, heterarchical conceptions. Even if in the current debate some of the positions may be relatively close, highlighting the contrast between the two strands will be useful to probe more deeply into their respective foundations and into the choices we face in the conceptualisation and construction of the postnational legal order.

The contest between constitutionalism and pluralism has so far largely lacked a common basis - pluralists have typically made their case on analytical grounds, while constitutionalists have mostly turned to the normative sphere. So whereas pluralism seems to provide a strong (though contested) interpretation of the current, disorderly state of postnational law, constitutionalism - if not yet realised today - appears as the more attractive vision for the future. ${ }^{4}$ As I will try to show in this paper, however, this picture does not quite capture the normative appeal of the pluralist approach. In a postnational society characterised by diversity and rapid change, constitutionalist models face serious difficulties and their appeal risks being diluted by the (necessary) accommodation of the divergent interests and values of different parts of the polity. Pluralism, on the other hand, has significant strengths in providing adaptability, space for contestation, and a possibility of steering between conflicting supremacy claims of different polity levels. This does not imply that a pluralist approach would be free from

$1 \mathrm{~N}$. Walker, 'Beyond boundary disputes and basic grids: Mapping the global disorder of normative orders' (2008) 6 International Journal of Constitutional Law 373.

2 See the survey ibid.

${ }^{3}$ See, e.g., N. Walker, 'The Idea of Constitutional Pluralism' (2002) 65 Modern Law Review 317.

${ }^{4}$ See, e.g., J. Baquero Cruz, 'The Legacy of the Maastricht-Urteil and the Pluralist Movement' (2008) 14 European Law Journal 389, 417-418. 
difficulties, or that it would be necessarily superior to constitutionalism on all counts. But it would likely resonate better with the divided allegiances and preferences in postnational society which, more than substantive evaluations, should guide any design of the institutional order in and beyond the state.

The paper develops this argument in five steps. It begins by analysing the normative claims of postnational constitutionalism - by reconstructing constitutionalism's appeal as a model for domestic order and by inquiring into the extent to which this appeal carries over into the very different postnational environment. The focus here is on constitutionalism's engagement with divided societies - the institutional forms it has developed to respond to deep diversity and the problems it continues to face in this respect. This focus should help in assessing constitutionalism's prospect in a society such as the postnational which, more than anything, is diverse; and it should help to avoid the idealisations implicit in analogies with more benign domestic circumstances. In the following section, the paper then lays the conceptual ground for an analysis of a pluralist order as an alternative to a constitutionalist one, by identifying more clearly different understandings of pluralism and their implications. On this basis, the paper begins to inquire into the normative appeal of pluralism by developing further the three main arguments suggested so far in the literature - greater adaptability, the provision of contestatory space and the equidistance to conflicting claims to ultimate authority. Despite their merits, though, such substantive benefits alone will be insufficient to ground our structural choices; they have to be integrated into an account that gives much greater weight to procedures in the determination of a polity's structural framework. In a next step I outline such a more procedural, participatory account and how it would frame the contest between constitutionalism and pluralism. It is on this basis that pluralist proposals are likely to gain their real strength, which lies in their greater resonance with current, divided social practices towards the multiplicity of sites of political authority. Even so, a pluralist order faces fundamental problems, and the final section begins to address some of them, including those related to power, stability and democracy. In all these respects, pluralism may not emerge as flawless, but the constitutionalist alternative rarely fares much better and is often likely to fare worse. In the postnational order, ideal solutions are scarce - yet among the non-ideal ones, pluralism may be the least problematic.

\section{POSTNATIONAL CONSTITUTIONALISM AND ITS LIMITS}

Constitutionalism has become attractive as a vision for ordering the postnational space mainly because of the close link it provides with central categories of domestic political order. As domestic, European and global politics have become ever more intertwined and much public power has moved beyond the state, it seems only natural to extend domestic concepts of legitimacy and democracy into 
the new, broader spaces. If there was a justification for a different - and thinner notion of legitimacy in the international sphere before, it is now severely weakened, not least because the main tool to legitimate international law-making inter-state consent - has lost much of its force in an era of delegated law-making, soft law and, more broadly, global governance. ${ }^{5}$ Having recourse to domestic concepts for structuring and limiting government then seems to be an obvious move, and constitutionalism a prime candidate.

\section{CONSTITUTIONALISM’s APPEAL}

Unsurprisingly, then, both in the EU context and in the broader global realm constitutionalist discourse has grown exponentially in the last decade, reflecting and building on the importance of constitutionalism in the national context. Over the last two centuries, in the wake of the American and French revolutions, constitutionalism has become key to ensuring the legitimacy of domestic governments, and it has come be regarded as a unique institutional reflection of central tenets of modern political theory. ${ }^{6}$ The form of the constitution, as a higher law that frames, organises and limits the public power exercised in a polity, is seen to promote the joint realisation of the rule of law and of democracy, marrying the rule of men with the rule of laws and thus appealing to liberals and republicans alike. ${ }^{7}$ All government in the constitutional state has to act within the limits the constitution sets, but because the constitution supposedly derives from 'the people', these limits appear as expressions rather than limitations on democratic action. It is precisely through the constitution that a people can come together and, in a form of 'higher politics', set the terms of their association and representation, thereby vindicating their power to frame the daily politics conducted by their representatives at a distance. ${ }^{8}$

Yet the appeal of constitutionalism goes further than this. It also encapsulates the very modern, Enlightenment idea of agency: it provides a form by which a polity can wrestle its affairs back from the forces of chance, history and power and remake, indeed refound, its institutions in a comprehensive way. Ideally, at the moment of constitution-making all traditional sites of public power come under scrutiny and are examined in the light of reason, and none of them can survive outside the constitutional framework. ${ }^{9}$ Yet constitutionalism does not draw its appeal exclusively from questioning tradition; in part, it is also seen as a tool to strengthen it. Constitutions may entrench universal values, but they typically also give expression to particularist ones, thus restating the distinct foundations of the

\footnotetext{
5 See, e.g., J.H.H. Weiler, 'The Geology of International Law - Governance, Democracy, Legitimacy' (2004) 64 Zeitschrift für ausländisches öffentliches Recht und Völkerrecht 547.

${ }^{6}$ See D. Grimm, Die Zukunft der Verfassung (Frankfurt am Main: Suhrkamp, 1991) ch. 2.

7 On the complementarity of, and tension between, both concepts in American constitutionalism, see, e.g., F. Michelman, 'Law's Republic' (1988) 97 Yale Law Journal 1493, 1499-1500.

8 B. Ackerman, We the People, vol. 1 (Cambridge, Mass.: Harvard University Press, 1991).

9 C. Klein, 'Pourquoi écrit-on une constitution?' in M. Troper \& L. Jaume (eds), 1789 et l'invention de la constitution (Bruxelles: Bruylant, 1994) 89, 94-96.
} 
polity and sometimes allowing for a deepening of the national community through attachment to common values and institutions. This provides the link to that other central element of modern political theory, the idea of the nation, and helps integrate the polity over time, leading to greater stability of its institutions. ${ }^{10}$ In more liberal terms, this stabilising and integrating function is captured in diagnoses of an emerging 'constitutional patriotism'.11

This may be an ideal characterisation of what constitutions and constitutionalism may embody, but it is easy to see why it has given them sufficient appeal to become such central elements of modern politics and political theory. And it is clear why it would be a crucial resource for thinking about, and constructing, institutions beyond the nation state. After all, the institutional structure at the global level today often appears just as accidental, as 'monstrous'12 as that of early modernity which modern, revolutionary constitutionalism sought to overcome. Substituting reason and agency for historical force and material power in the design of global institutions must then appear just as urgent, and using constitutionalism to that end becomes an obvious choice. A global constitution could safeguard individual rights, hedge global governance in, and help popular sovereignty to catch up with the expansion of the political space beyond state boundaries. And finally, it could crystallise the values of, and give shape to, an international community that so far has remained largely abstract.

In varying constellations, these themes dominate the burgeoning debate on postnational constitutionalism. ${ }^{13}$ Many of the proposed constitutionalisms, both for the European and the global contexts, focus on one particular theme, often that of legalisation, the limitation of powers, and the entrenchment of individual rights. ${ }^{14}$ Others emphasise the community-building, integrative function of constitutionalisation, the commonality of values expressed in norms of a particular, elevated status in international law. ${ }^{15}$ And yet others see the very fact of emerging hierarchies in the international legal order as a reflection of a move towards a constitution, towards a 'higher' law that frames and limits global politics. ${ }^{16}$ Such visions, however, connect only partly to the domestic tradition of constitutionalism described above. They connect to a particular tradition, that of 'power-limiting' constitutionalism that has been strong in England and in 19th century Germany, but in influence and appeal has since given way to the more comprehensive, foundational type of constitutionalism the American and French revolutions have made prominent and that has found almost universal acceptance

\footnotetext{
10 See, e.g., D. Grimm, 'Integration by constitution' (2005) 3 International Journal of Constitutional Law 193.

11 See J.-W. Mueller, Constitutional Patriotism (Princeton: Princeton University Press, 2007).

12 Severinus de Monzambano (Samuel Pufendorf), De statu imperii Germanici (1667) ch. VI, \$9.

13 For a survey, see N. Walker, 'Taking Constitutionalism Beyond the State' (2008) 56 Political Studies 519.

14 See the overview of such approaches in J. Klabbers, 'Constitutionalism Lite' (2004) 1 International Organizations Law Review 31, 32-36.

15 See, e.g., E. de Wet, 'The Emergence of International and Regional Value Systems as a Manifestation of an International Constitutional Order' (2006) 19 Leiden Journal of International Law 611.

16 See, e.g., A. Peters, 'Compensatory Constitutionalism: The Function and Potential of Fundamental International Norms and Structures' (2006) 19 Leiden Journal of International Law 579.
} 
as a yardstick for governmental legitimacy. ${ }^{17}$ By insisting on a constitution as the comprehensive foundation of public power - not only a partial limitation - this foundational type combines the various dimensions of appeal in the domestic context, and it is this tradition that should therefore guide us in any effort at translating "constitutionalism" into the postnational sphere.

This foundational variant of constitutionalism will be my focus in this paper, and it has also proved increasingly attractive in the practice and theory of postnational politics. The most tangible result has been the European constitutional treaty, which was seen as an opportunity to place the European Union on a new foundation and open up stronger legitimacy resources; among theorists, Jürgen Habermas, for example, explicitly defends a vision of foundational constitutionalism for Europe. ${ }^{18}$ On the global level, the United Nations Charter has been reinterpreted by some as a constitutional document, towering above and framing other regimes of global governance as well as individual states. ${ }^{19}$ More broadly, though, such a tendency is visible in a multiplicity of approaches that seek to give the current, largely unstructured, historically accidental and power-driven order of global governance a rational, justifiable shape in which the powers of institutions and their relationships with one another are clearly delimited.

Such approaches are widespread among political theorists and legal scholars alike. A good example is David Held's quasi-federal vision of the global order. ${ }^{20}$ Held envisions a political structure in which all those affected by a particular issue have a right to participate in decisions on it; combined with a principle of subsidiarity, this results in a layered setup of institutions with a distribution of powers among the different levels that resembles federal states. He acknowledges that this distribution of powers will - as in many national contexts - often be contested and complex to resolve, but in his view, a resolution in a public setting based on an overarching principle is preferable to leaving them 'to powerful geopolitical interests (dominant states) or market based organizations to resolve them alone'. ${ }^{21}$ In good constitutionalist fashion, a principled construction of the global institutional order is thus presented as an antidote to power, history and chance. $^{22}$

\footnotetext{
${ }^{17}$ On the two types, see C. Möllers, 'Verfassunggebende Gewalt - Verfassung - Konstitutionalisierung' in A. v. Bogdandy (ed.), Europäisches Verfassungsrecht (Berlin, Heidelberg: Springer, 2003) 1, 3-18.

${ }^{18}$ J. Habermas, The Postnational Constellation (trans. M. Pensky, Cambridge, Mass.: MIT Press, 2001) ch. 4.

${ }^{19}$ B. Fassbender, 'The United Nations Charter as Constitution of the International Community' (1998) 36 Columbia Journal of Transnational Law 529.

${ }^{20}$ D. Held, Democracy and the Global Order (Cambridge: Polity Press, 1995).

${ }^{21}$ D. Held, 'Democratic Accountability and Effectiveness from a Cosmopolitan Perspective' (2004) 39 Government \& Opposition 365, 382.

${ }^{22}$ For similar proposals see, e.g., I.M. Young, Inclusion and Democracy (Oxford: Oxford University Press, 2000) ch. 7; and among legal scholars, M. Kumm, 'The Legitimacy of International Law: A Constitutionalist Framework of Analysis' (2004) 15 European Journal of International Law 907.
} 


\section{CONSTITUTIONALISM AND PostNational Society}

Such grand designs are appealing for their readiness to disregard the vagaries of the current, path-dependent, often accidental shape of global governance and their attempt to realise human agency in the construction of common institutions. In that sense, they do indeed recapture the spirit of the early constitutionalists of the American and French revolutions, so neatly reflected in Hegel's dictum that never before 'had it been perceived that man's existence centres in his head, i.e. in Thought, inspired by which he builds up the world of reality.'23 Postnational constitutionalism seems to be the tool to institutionalise precepts of transboundary, global justice and thus enrich the common values of international society and further its integration into a common polity of mankind.

Yet it is this integrationist, universalising tendency that also provokes concerns for its potential disconnect with social realities. For Habermas, for example, the preconditions for the collective exercise of public autonomy, a central element of foundational constitutionalism, are simply lacking in the current, diverse international society, forcing us to limit our aspirations. ${ }^{24}$ And for Iris Young, the idea of common political institutions to tackle problems of global justice, as attractive as it might be in the abstract, stands in tension with the allegiances of individuals to their particular, mostly national, communities and their ensuing claims for self-determination. ${ }^{25}$

It is indeed the divided character of the global polity that poses the greatest challenge to the globalisation of constitutionalism. After all, international society is characterised by a high degree of diversity and contestation, and even the small signs of increasing convergence that we can observe are by no means unambiguous. Diversity may today not be as radical as it was in the 1970s, when Hedley Bull's vision of an anarchical society within a pluralist international order appeared as highly plausible, given the deep-seated frictions between West and East and North and South. ${ }^{26}$ Today, we can find indications of a stronger solidaristic, perhaps even cosmopolitan turn in greater agreement on fundamental principles, such as basic human rights, and in a much higher degree of institutionalisation of policy- and law-making beyond the state. ${ }^{27}$ Whether this warrants the diagnosis of an emerging 'international community', however, is still questionable ${ }^{28}$, and it certainly is if we think of such a community as one that its members rank supreme in the sense that they accept global solutions to problems as trumping those of other communities (regional, national, subnational).

\footnotetext{
${ }_{23}$ G.W.F. Hegel, The Pbilosophy of History (J. Sibree, trans., Buffalo: Prometheus Books, 1991) 447 (Part IV, Section III, Chapter III).

24 J. Habermas, Der gespaltene Westen (Frankfurt am Main: Suhrkamp, 2004) ch. 8. Habermas only sees potential for 'power-limiting', rather than foundational, constitutionalism at the global scale; ibid 138.

${ }^{25}$ Young, n 22 above. Young seeks to respond through a federal-style model that is 'jurisdictionally open'; I will return to this theme below.

${ }^{26}$ H. Bull, The Anarcbical Society (London: Macmillan, 1977).

27 See A. Hurrell, On Global Order (Oxford: Oxford University Press, 2007) ch. 3 , 4.

28 See A. Paulus, Die internationale Gemeinschaft im Völkerrecht (München: C.H. Beck, 2001).
} 
Allegiance to national communities may have been complemented by those of a local, religious, ideological nature, some of which with a clear transnational, perhaps even cosmopolitan tinge, and this may have led to a world of multiple rather than exclusive loyalties, and to a variety of foundational discourses competing for dominance. ${ }^{29}$ But cultural, ideological, religious and political diversity remains strong and is often coupled with an insistence on ultimate authority on the national level - reflecting a vision of the international order as one of intergovernmental negotiation and exchange rather than an expression of a deeper common project. ${ }^{30}$ Even in the European Union, where diversity, though still prominent, is clearly weaker than in a global context, allegiance to national communities still trumps that to Europe by a large margin. ${ }^{31}$

All this may not be fatal to the postnational constitutionalist project; after all, just as attempts have been undertaken to move from democracy to 'demoicracy' 32 , we might come to imagine a constitutionalism on a plurinational basis. ${ }^{33}$ But such an undertaking faces serious challenges based on critiques that have for long highlighted the difficulties modern constitutionalism has had in diverse societies. James Tully's is one of the most prominent among them. For Tully, modern constitutionalism as it has emerged with the American and French revolutions and has framed much of political thought ever since - cannot cope with serious social and cultural diversity because of its strong link to ideas of impartiality and uniformity. ${ }^{34}$ Given its roots in the Enlightenment, it seeks to erect a regular, wellstructured framework of government based on reason and distinct from the irregular, historically grown structures that characterised previous eras. In this uniformity, however, it fails to reflect the different customs and culturallygrounded ideas of particular groups in society; and this even more so if these groups do not subscribe to the liberal vision of a 'modern', free individual, able and willing to transcend her history and culture and ready to engage with all others in an unconditional deliberation over the course of the common polity. The impartiality sought through such mechanisms as Rawls's veil of ignorance or Habermas's adoption of the interlocutor's perspective only makes sense if individuals are ready to leave particular allegiances behind; for all others, it means exclusion from the supposedly neutral frame. ${ }^{35}$

29 M.J. Sandel, Democracy's Discontent (Cambridge, Mass.: Harvard University Press, 1996) 338-351; J. Dryzek, Deliberative Global Politics (Cambridge: Polity Press, 2006) ch. 1; see also J. Bohman, Democracy across Borders (Cambridge, Mass.: MIT Press, 2007) 28-36.

${ }^{30}$ See Hurrell, n 27 above, ch. 5.

31 See, e.g., the Eurobarometer of Autumn 2003, 27-28, available at http://ec.europa.eu/ public_opinion/archives/eb/eb60/eb60_en.htm; see also J.T. Checkel \& P.J. Katzenstein (eds), European Identity (Cambridge: Cambridge University Press, 2009).

32 E.g., Bohman, n 29 above; K. Nicolaidis, "We, the Peoples of Europe..." (2004) Foreign Affairs, November \& December issue, 97-110.

33 E.g., S. Tierney, Constitutional Law and National Pluralism (Oxford: Oxford University Press, 2004).

${ }^{34} \mathrm{~J}$. Tully, Strange Multiplicity: Constitutionalism in an age of diversity (Cambridge: Cambridge University Press, 1995) ch. 2 and 3.

${ }^{35}$ For related critiques, see, e.g., M.J. Sandel, 'The Procedural Republic and the Unencumbered Self, (1984) 12 Political Theory 81; C. Taylor, 'The Politics of Recognition', in id., Philosophical Arguments (Cambridge, Mass.: Harvard University Press, 1995) 225-256. 
For Tully then, the integrationist, universalising tendencies of foundational constitutionalism sit uneasily with the diverse identities of individuals in divided societies; the emphasis on common values and self-government by a shared, overarching collective stands in tension with their diverging allegiances. Historically, the tension may have been resolved by policies of nation-building which, over time, succeeded in overcoming linguistic and cultural divides but involved measures of forced assimilation that today would be regarded as grave violations of human rights. Such forcible integration would in any event be hardly conceivable in international society. For constitutionalism to remain attractive as a model for the global polity, it would thus have to find other ways to cope with that polity's deep diversity.

\section{The Constitutionalist Accommodation of Diversity}

Tully accuses modern constitutionalism of creating an 'empire of uniformity', but in this he fails to appreciate the many ways in which it has come to respond to the challenges of divided societies. It may have started out as a quest for a reasoned, uniform order, and as we have seen, much of its appeal derives from this aspiration. Also today, many constitutional states pursue integrationist aims, build common institutions and seek to 'privatise' diversity, relying on individual rights to accommodate differences in ways of life. ${ }^{36}$ But while this is often seen as a suitable solution in societies that are characterised by crosscutting cleavages, it is more problematic where the divides are stable and fairly unidimensional and thus lead to structural minorities with little hope for sharing power in common institutions. Responses to such situations typically eschew strong integrationist ideals and seek instead to deal with diversity through accommodation, mainly in the form of consociationalism and/or devolution. ${ }^{37}$ It is such responses to diversity that a postnational constitutionalism might be able to draw on for inspiration.

\section{Consociationalism and federalism}

Consociationalism is characterized by an insistence on common decision-making: prominent in a number of smaller European countries especially in the postwar period and later adopted in several other settings, consociationalism seeks to manage deep disagreement through executive power sharing and the creation of veto positions for minority groups. ${ }^{38}$ These force all actors to reach common ground rather than impose their views on the others; none of the constituencies enjoys formal primacy. The precise institutional arrangements may vary, as do the mechanisms to determine the relevant groups, but central to consociationalism is

\footnotetext{
${ }^{36}$ For a theoretical defence, see B. Barry, Culture and Equality: An Egalitarian Critique of Multiculturalism (Cambridge, Mass.: Harvard University Press, 2002).

${ }^{37}$ See the survey of the debate in J. McGarry, B. O'Leary \& R. Simeon, 'Integration or accommodation? The enduring debate in conflict regulation' in S. Choudhry (ed), Constitutional Design for Divided Societies: Integration or Accommodation? (Oxford: Oxford University Press, 2008) 41; see also Tierney, n 33 above.

${ }^{38}$ See A. Lijphart, Democracy in Plural Societies (New Haven: Yale University Press, 1978); id, Thinking About Democracy: Power Sharing and Majority Rule in Theory and Practice (London: Routledge, 2008).
} 
the assumption that societal groups should not only be granted autonomy rights as regards their own cultural and linguistic affairs but should also enjoy a particular, protected position in the central decision-making structure of the state. Otherwise, consociationalists believe, those groups will be at a permanent disadvantage in the struggle over common policies, and ever greater antagonism and conflict are likely to ensue. ${ }^{39}$

Federalist responses, on the other hand, focus less on central, common decision-making and emphasise instead the need to devolve as many state functions as possible to the groups that make up society. This can occur in the form of territorial pluralism in which those functions are exercised by federal units that largely follow the lines of inter-group boundaries. ${ }^{40}$ Such an approach can be combined with consociationalist, co-decision arrangements at the federal level, but it is feasible only if the relevant groups are territorially concentrated. Moreover, it does not require fully federal states but can instead involve asymmetrical arrangements, granting minority groups particular powers beyond those of majority groups because the latter find sufficient representation in central decision-making processes. However, when groups are territorially dispersed, devolution has to follow personal rather than territorial lines and is accordingly more limited in its extent; it typically focuses on group rights to govern cultural and educational affairs.

On the postnational level, as most divides follow territorial lines, both consociationalism and territorial federalism, or a combination of both, may provide resources for the accommodation of diversity. This may alleviate some of the concerns raised by Tully, as uniformity would be less at the centre of the constitutionalist project than in its classical variety. However, it might also dilute the appeal of the project that, as we have seen, has originally drawn precisely on the virtues of reason, order and collective decision-making. The accommodationist response to diversity, though perhaps inevitable, may thus involve serious tradeoffs.

\section{Trade-offs}

The most obvious such trade-off concerns the integrative force of constitutionalism and the stability that is seen to flow from it. Foundational constitutionalism is typically regarded as a potent tool to integrate society, by creating a common framework as an expression of both common values and collective decision-making processes. The need to find common solutions does indeed seem to lead typically to an attenuation of diversity, while accommodationist approaches may help entrench the boundaries between different groups and are often seen as widening, rather than closing the gaps in

\footnotetext{
${ }^{39}$ But see also the critiques, e.g. D. Horowitz, 'Constitutional Design: Proposals Versus Processes' in A. Reynolds (ed), The Architecture of Democracy: Constitutional Design, Conflict Management, and Democracy (Oxford: Oxford University Press, 2002) 15; B. Barry, 'Political Accommodation and Consociational Democracy' (1975) 5 British Journal of Political Science 477.

${ }^{40}$ See, e.g., the discussion in McGarry, O’Leary \& Simeon, n 37 above, 63-67.
} 
society, thus creating greater instability and potentially leading to secession or break-up. ${ }^{41}$ Yet in deeply divided societies, the option of integrationist policies rarely exists; minority groups are typically not ready to agree to them for fear of losing out to the majority. And if integration is pursued despite such opposition, it will typically lead to greater friction, resistance and instability of the overall constitutional structure. Accommodation may not come with the full stabilising promise of the original, more unitary strain of foundational constitutionalism, but there is little alternative to it when divisions run deep. ${ }^{42}$

The second trade-off concerns the effectiveness of collective decisionmaking. As I have sketched above, constitutionalism draws much of its appeal from the realisation of public autonomy over collective affairs in the face of forces of history and chance. But by many, especially majority groups, accommodation may be seen precisely as a surrender to such forces. Even if normatively justified ${ }^{43}$, it often comes to be seen as a respect for difference that is based on historicallygrown, passion-based allegiances quite in contrast with detached, reasoned construction. And accommodationist approaches may dilute the promise of public autonomy on yet another level. Because consociationalism emphasises the commonality of decision-making and, as a result, veto rights of minority groups, it runs the risk of institutionalising blockade: it might lead to a 'joint-decision trap'44 and thus limit collective decision-making capacity significantly. For the greater the number of groups in society (and in postnational society the number is bound to be high), the greater the risk that collective negotiations collapse. ${ }^{45}$ And if unanimity has to be achieved, policies will have to be pareto-optimal - they have to benefit each and every group, but this severely reduces the range of possible options and limits prospects of, for example, distributive justice. ${ }^{46}$

Another challenge that consociationalism poses to the ideal of public autonomy lies in the extent of individual participation in government. ${ }^{47}$ One of the central elements of consociationalism is its reliance on the cooperation of elites: because on many issues genuine consensus among the different groups will be elusive, problem-solving requires bargaining, package-deals, logrolling. This, however, can only be achieved by elites that stand in constant contact with each other and are socialized into cooperation. Stronger participation of the general public in the various groups renders this cooperation difficult because it is usually focused only on a particular decision, not the whole of the deal struck.

${ }^{41}$ See, e.g., R.H. Pildes, 'Ethnic identity and democratic institutions: A dynamic perspective' in Choudhry, n 37 above, 173-201.

${ }^{42}$ McGarry, O'Leary \& Simeon, n 37 above, 85-87.

${ }^{43}$ For normative defences of group rights, see W. Kymlicka, Multicultural Citizenship (Oxford: Clarendon Press, 1995); N. Torbisco Casals, Group Rights as Human Rights (Dordrecht: Springer, 2006).

${ }^{44}$ F. Scharpf, 'Die Politikverflechtungsfalle: Europäische Integration und deutscher Föderalismus im Vergleich' (1985) 26 Politische Vierteljabresscbrift 323, 346-350.

45 Accordingly, also for Lijphart consociational orders ideally operate with no more than four main groups; see Lijphart, Democracy in Plural Societies, n 38 above, 56.

46 On such problems in the EU context see, e.g., F. Scharpf, 'The Joint-Decision Trap Revisited' (2006)

44 Journal of Common Market Studies 845, 851.

${ }^{47}$ See, e.g., Dryzek, n 29 above, 50-51. 
Accordingly, as Lijphart stresses, '[i]t is ... helpful if [leaders] possess considerable independent power and a secure position of leadership'. ${ }^{48}$ Even though this is not incompatible with public participation in general, it considerably limits its scope. ${ }^{49}$ And the introduction of further accountability mechanisms into the already difficult framework of negotiations on the postnational level would only aggravate the risk of a complete blockade of decision-making.

\section{Remaining tensions}

Yet even with such tools, and despite these trade-offs, the accommodation of diversity in foundational constitutionalism has limits. After all, if it wants to retain its central promise - to create a comprehensive framework for all public power in a given polity under the rule of law - constitutionalism has to ultimately resolve the tension between the sovereignty claims of both the federal and the group level, if only by defining rules for constitutional amendment. Visions of a federalism with 'suspended' ultimate authority, which were influential until the late $19^{\text {th }}$ century, stand in conflict with this comprehensive ambition and find little reflection in contemporary federal orders. ${ }^{50}$ This leaves foundational constitutionalism with two options: it either resolves the sovereignty question in favour of the groups, and their interaction remains a non-constitutionalist affair; it is that of a federation under international law. Or it resolves it in favour of the federal level (for example, by denying group vetos in amendment processes); it can then realise the constitutionalist promise to some extent, but this realisation might remain formal as long as some groups actively contest the solution. One may only think of the Canadian constitutional crisis, provoked by Québec's insistence on a unilateral right to secede, throughout the 1980s and 1990s. The federal claim to define the rules for constitutional amendment (including the framework for secession) and thus to regulate the relationship with its constituent units, remained fragile in the face of resistance by a powerful minority - in fact, it antagonised this minority only further. ${ }^{51}$ Unless the constitutionalist ambition to create a comprehensive framework meets matching societal conditions, such fragility is bound to continue, and the hope to create a constitutional framework for politics keeps being called into question by its dependence on politics.

Constitutionalism thus finds itself in a dilemma when faced with divided societies. It can retain its purity, pursue the integration of society and seek to level difference, but this is typically not only normatively problematic but also practically impossible; it may enflame tensions rather than calm them. However, the alternative - accommodation - also comes at a high cost: as we have seen, it diminishes the constitutionalist promise insofar as it reduces the potential for

\footnotetext{
48 Lijphart, Democracy in Plural Societies, n 38 above, 50.

${ }^{49}$ For a nuanced account, see McGarry, O’Leary \& Simeon, n 37 above, 82-84.

50 See R. Schütze, 'Federalism as Constitutional Pluralism: Sovereignty Suspended', unpublished manuscript (on file with the author); S. Oeter, 'Föderalismus' in von Bogdandy, n 17 above, 59, at 76-92.

51 S. Choudhry, 'Does the world need more Canada? The politics of the Canadian model in constitutional politics and political theory' in Choudhry, n 37 above, 141, at 159-171.
} 
long-term social stability, for public autonomy and often enough also for the rule of law. After all, in order to remain true to its core, constitutionalism has to maintain the idea of a comprehensive framework that assigns different organs and groups their places. And this requires hierarchies that all too often might stand in tension with the (diverging) claims of different parts of society.

This element of hierarchy brings me back to Tully's critique I have mentioned above. After what we have seen in this section, this critique seems overdrawn in its attack on constitutionalism's 'empire of uniformity' - constitutionalist thought and practice certainly know more ways of accommodating difference than Tully gives credit for. But he is right in pointing to the fact that the supposed commonality of the constitutional project requires members of the 'nation' to recognise it as the primary political framework, taking precedence over whatever other structures might exist in sub-groups. It presupposes the acceptance of a priority of the common over the particular (typically within limits of human rights) - an acceptance we might not find among distinct cultural groups within states, and certainly not among states vis-à-vis the 'common' European or global realm. This emphasis on the collective, the common framework, poses not only normative problems from the perspective of minority groups, but it may also aggravate the tensions within society and thus create less rather than more stability. Sovereign authority is simply too precious, and the quest for it typically attracts pernicious contest and drives competing groups further apart. ${ }^{52}$ But such a dynamic may be difficult to avoid in the binary, hierarchical structure of constitutionalism. We may thus have to consider eschewing principled, constitutional frameworks in such circumstances and instead work around societal divides in a more pragmatic fashion. As John Dryzek puts it, in some circumstances ' $[t]$ he peace is disturbed only by philosophers who believe a constitutional solution is required. ${ }^{53}$ If this is true in domestic societies with high degrees of diversity, it will be even more so in the postnational context.

\section{THE PLURALIST ALTERNATIVE}

The challenge of societal diversity thus leaves constitutionalism in a quandary. The more it seeks to accommodate diversity, the more it loses its original appeal, and still, if it wants to maintain some of its promise, it has to uphold the ambition of forming a comprehensive framework, thus creating tension with claims for ultimate authority from different sides. This creates a significant problem in our quest for a structuring model for the postnational space. As I suggested in the introduction, the classical model - the idea of an inter-national order in which ultimate authority lies with states - is unable to cope with the increasing

${ }^{52}$ Dryzek, n 29 above, ch. 3.

53 ibid 64. 
enmeshment of levels of governance in today's globalised world. Constitutionalism, given its domestic pedigree and appeal, would have seemed the obvious candidate for succeeding it, but our discussion above indicates that it conflicts with the persistent diversity of the postnational polity. Yet how else could we conceive of the global legal and political order?

In this paper, I want to examine (and eventually defend) an alternative model, pluralism. 'Pluralism' suggests a particular responsiveness to issues of diversity, and it might also sound appealing as a more positive approach to phenomena of fragmentation that, in the international law literature at least, have provoked considerable anxiety. ${ }^{54}$ Yet pluralism has many meanings, and it can serve as a description of the shape and diversity of society, of substantive commitments in matters of rights or institutions, or of the structure of a polity's institutions. It is the latter meaning that interests me most, as it operates on the same (structural) level as constitutionalism and may therefore provide a true alternative. Yet even here, the usage of pluralism varies widely. The differences could be seen as a matter of degree - as between 'soft' and 'hard' or 'moderate' and 'radical' pluralism. Analytically, though, they are better captured as differences in kind, as between what may be termed 'institutional' and 'systemic' pluralism.

To illustrate this distinction, and to work out more clearly what could be an alternative model to the constitutionalist one, it is worth taking a closer look at Neil MacCormick's work which has inspired much recent pluralist thinking. ${ }^{55}$ MacCormick sought to theorise the impact of the conflicting supremacy claims of the national and Union levels in the European Union and came to regard the resulting legal structure as one in which both levels, as systemic units, had internally plausible claims to ultimate authority; their conflict was due to the fact that they did not agree on the ultimate point of reference from which they were arguing. For the national level, national constitutions remained the ultimate source of authority, and all exercises of public power (including by the EU) had to be traced back to them; for the EU, the EU treaty was seen as independent from, and superior to, national law including national constitutions. In MacCormick's view, there was thus no common legal framework that could have decided the conflict the two views were (on a fundamental level) irreconcilably opposed; the two levels of law ran in parallel without subordination or external coordination. This description borrowed some of its ideas from sociological and anthropological accounts of legal pluralism that had become influential since the $1970 \mathrm{~s}^{56}$, but took the idea beyond the relationship of official and non-official law (or norms) that those studies were interested in and applied it to the coexistence of different

\footnotetext{
54 See the analysis in M. Koskenniemi \& P. Leino, 'Fragmentation of International Law? Postmodern Anxieties' (2002) 15 Leiden Journal of International Law 553.

55 N. MacCormick, 'Beyond the Sovereign State' (1993) 56 Modern Law Review 1; id, 'The MaastrichtUrteil: Sovereignty Now' (1995) 1 European Law Journal 259.

56 See S.F. Moore, 'Law and Social Change: the Semi-Autonomous Social Field as an Appropriate Subject of Study' (1973) 7 Law \& Society Review 719; J. Griffiths, 'What is Legal Pluralism?' (1986) 24 Journal of Legal Pluralism 1; S.E. Merry, 'Legal Pluralism’ (1988) 22 Law \& Society Review 869.
} 
official systems of law, all with their own Grundnormen or rules of recognition. In this sense, MacCormick's approach was one of 'systemic' (or in his words, 'radical') pluralism. ${ }^{57}$

Whether consciously or not, this approach had ancestors not only in medieval thought ${ }^{58}$, but also in the early theory and practice of federalism. ${ }^{59}$ Especially the situation in the United States after the constitution of 1787 had created an awareness that the classical categories - unitary state or federal union under international law - did not adequately reflect the character of federal polities. In the US, the constitution was described as 'neither a national nor a federal Constitution, but a composition of both' 60 , and it certainly sought to balance the powers of the federal government and those of the states. More importantly perhaps, it left unsettled rival claims to ultimate authority: throughout the first half of the $19^{\text {th }}$ century, such authority was claimed for both the federal and the state levels, and the contest was eventually decided only through the civil war. ${ }^{61}$ In Europe, parallel conceptions existed (and were influential until the late $19^{\text {th }}$ century ${ }^{62}$ ), and it was Carl Schmitt who later captured them most cogently in his theory of federal union by placing the undecided, 'suspended' character of ultimate authority at its center. ${ }^{63}$

If Neil MacCormick initially envisioned the EU in a similar way, he softened his account considerably in his later work. Mindful of the risk of friction and collision inherent in an unregulated parallelism of different orders, he came to see a greater potential for coordination in the overarching framework of international law. 'Pluralism under international law', as he terms it, is in fact a monist conception, but one that assigns EU law and domestic constitutional law equal positions and does not subordinate one to the other as a matter of principle. ${ }^{64}$ This has been criticised for taking the edge out of the approach, and analytically it is indeed categorically distinct from the systemic pluralism MacCormick had initially diagnosed. It accepts pluralism not on the systemic level, but only in the institutional structure - different parts of one order operate on a basis of coordination, in the framework of common rules but without a clearly defined hierarchy, in a form of what I would call 'institutional pluralism'. The tamed nature of this variant can be glanced when considering other articulations of it, for example Daniel Halberstam's account of 'interpretive pluralism' under the US

\footnotetext{
57 See N. MacCormick, 'Risking Constitutional Collision in Europe?' (1998) 18 Oxford Journal of Legal Studies 517, 528-532.

${ }^{58}$ H.J. Berman, Law and Revolution: The Formation of the Western Legal Tradition (Cambridge, Mass.: Harvard University Press, 1983) 115-119.

${ }^{59}$ Schütze, n 50 above; see also O. Beaud, Théorie de la Fédération (Paris: PUF, 2007).

60 A. Hamilton, J. Madison \& J. Jay, The Federalist Papers (L. Goldman, ed, Oxford: Oxford University Press, 2008) 192 (J. Madison, Federalist No. 39).

${ }^{61}$ See A.R. Amar, 'Of Sovereignty and Federalism' (1987) 86 Yale Law Journal 1425, 1429-1466.

62 See, e.g., S. Oeter, 'Souveränität und Demokratie als Probleme in der "Verfassungsentwicklung" der Europäischen Union" (1995) 55 Zeitschrift für ausländisches öffentliches Recbt und Völkerrecht 659, 664-670; M. Stolleis, Geschichte des öffentlichen Rechts in Deutschland, vol. 2 (München: Verlag C.H. Beck, 1992) 365-368. ${ }^{63}$ C. Schmitt, Verfassungslebre [1928] (Berlin: Duncker \& Humblot, 9th ed, 1993) 371-375.

${ }^{64}$ MacCormick, n 57 above.
} 
Constitution. Pluralism, in this view, denotes the fact that the authority to interpret the United States Constitution is ultimately undefined, and that in the extreme case three organs compete for it - Congress, the President, and the Supreme Court. ${ }^{65}$ This may indeed lead at times to similar political dynamics as in instances of systemic pluralism such as the EU where Grundnormen themselves diverge. In particular, as Halberstam points out, the actors in both cases may have recourse to comparable sources of political authority to bolster their claims. ${ }^{66}$ But such similarities should not conceal the crucial difference that lies in the fact that interpretive pluralism operates with respect to a common point of reference constitutional norms that form a background framework and lay the ground for arguments about authority - while in systemic pluralism such a common point of reference within the legal or institutional structure is lacking. In Halberstam's example, conflict might not be fully regulated but it occurs in a bounded legal and political universe that contains (some) resources for its solution. Practically, the extent of this difference will depend on how thick the common framework is - in this respect, institutional and systemic pluralism may differ only gradually. If foundational constitutionalism and systemic pluralism mark the extremes of a continuum, institutional pluralism may occupy some place in the middle. Analytically, however, the difference between institutional and systemic pluralism is one in kind, defined by the presence vel absence of a common frame of reference.

Other pluralist approaches to postnational law follow a similarly institutionalist route. Mattias Kumm's 'cosmopolitan constitutionalism', for example, presents itself as pluralist as it does not seek to construct firm hierarchies between different levels of law. ${ }^{67}$ But this pluralism is embedded in a thick set of overarching norms, such as subsidiarity, due process or democracy, that are meant to direct the solution of conflicts. There may be no one institution to settle disputes, and thus such disputes may, as a matter of fact, remain undecided for a long time. This, however, is typical enough for all kinds of constitutional structures - after all, law or constitutions can never determine the outcome of conflicts, but only offer certain (institutional, normative) resources for their solution. Kumm's proposal may indeed be institutionally pluralist, but structurally it retains (as its self-description as cosmopolitan constitutionalism suggests) a constitutionalist character: in his vision, it is rules of 'hard law' - constitutional rules - that guide and contain conflict resolution. To use another example, Paul Schiff Berman situates his own approach clearly on the pluralist rather than the

65 D. Halberstam, 'Constitutional Heterarchy: The Centrality of Conflict in the European Union and the United States', in J.L. Dunoff \& J.P. Trachtman (eds.), Ruling the World? Constitutionalism, International Law and Global Government (Cambridge: Cambridge University Press, forthcoming) (available at http://ssrn.com/abstract=1147769).

66 ibid.

67 See M. Kumm, 'The cosmopolitan turn in constitutionalism: on the relationship between national constitutional law and constitutionalism beyond the state' in J.L. Dunoff \& J.P. Trachtman, n 65 above; see also Kumm, n 22 above. 
constitutionalist side ${ }^{68}$ and his account of the hybrid and contested nature of the global legal order is close to the systemic pluralism we see in the earlier work of MacCormick. Yet his discussion of the forms that may allow managing the resulting conflicts recalls the instruments by which constitutionalist models seek to accommodate diversity: limited autonomy regimes or subsidiarity principles reflect devolutionist ideas, while hybrid-participation regimes are close to models of consociationalism as set out in the previous section. ${ }^{69}$ Just as the later MacCormick, Schiff Berman seems to become afraid of the 'messy' picture he describes and clings to some degree of institutionalised harmony.

Harmony is also a prominent aim in another, more ambiguous take on postnational pluralism, that of Miguel Poiares Maduro. ${ }^{70}$ Maduro seeks to contain the risk of friction that results from the conflicting claims of national and EU law by introducing, as part of his idea of a 'counterpunctual law', a requirement for both levels to strive for coherence and integrity in the overall order. The formal status of this obligation remains open, and so does the nature of the resulting, common European order: the emphasis on commonality might suggest a tamed, 'institutional' pluralism, but the character of the coherence requirement can also be interpreted in a more radical fashion, as merely a moral requirement for the different actors to show respect to each other, to display an orientation towards cooperation rather than conflict. In this reading, it could be seen as a conflict-oflaws approach, much closer to systemic pluralism.

Conflict-of-laws ideas are sometimes used to infuse an ethos of recognition and respect into the rules that define the relationships of different levels of law in the postnational order. Christian Joerges takes this path, but it largely remains within a constitutional mindset, as it defines merely the substantive content of a framework that remains shared. ${ }^{71}$ Yet a conflict-of-laws model can also be seen as an architectural inspiration: as an inspiration to manage conflicts between different legal suborders not through overarching rules but through reliance on the capacity of those suborders to define adequate rules for mutual engagement. As in traditional conflict-of-laws, certain issues could then be subject to more than one set of rules, and the different legal subsystems would seek to define for themselves when to claim authority or cede it to another level. This forms the basis of the approach of Andreas Fischer-Lescano and Gunther Teubner: for them, the global legal order is irredeemably pluralist as the functional differentiation of society is reproduced (though not directly reflected) in a differentiation of legal subsystems,

\footnotetext{
${ }^{68}$ P. Schiff Berman, ‘Global Legal Pluralism', (2007) 80 Southern California Law Review 1155.

69 ibid 1196-1235.

${ }^{70}$ M. Poiares Maduro, 'Europe and the constitution: what if this is as good as it gets?' in J.H.H. Weiler \& M. Wind (eds), European Constitutionalism Beyond the State (Cambridge: Cambridge University Press, 2003) 74; id., 'Contrapunctual Law: Europe's Constitutional Pluralism in Action' in N. Walker (ed), Sovereignty in Transition (Oxford: Hart Publishing, 2003) 501.

${ }^{71}$ C. Joerges, 'Rethinking the Supremacy of European Law' EUI Working Paper Law 2005/12; id, 'Conflict of Laws as Constitutional Form: Reflections on International Trade Law and the Biotech Panel Report' RECON Online Working Paper 2007/3.
} 
all with their own particular rationalities. ${ }^{72}$ Interactions occur in network fashion, through interfaces defined by each subsystem in reaction to its environment, but without the hope for an overarching framework that would structure their relationships; too divergent are their own inner logics. Fischer-Lescano and Teubner's is a systemic pluralism without compromise or melancholical remnants of a constitutional structure, but it is also one in which the inevitability of social forces reigns and emancipatory ideas find little, if any, institutional home. If Martti Koskenniemi's critique that 'pluralism ceases to pose demands on the world' 73 fits anywhere, then here.

One does not have to be a follower of systems theory, though, to interpret the postnational legal order as systemically pluralist; in fact, many such accounts are driven by sociological observation based on actors and agency. Thus, Francis Snyder's analysis of global legal pluralism is based on the emergence and development of a plurality of 'sites of governance' through the strategic action of economic players across boundaries. ${ }^{74}$ And Boaventura de Sousa Santos's approach starts from the uses of law by actors, including social movements, in the interstices between normative orders where different sets of norms conflict and can be played out against each other. ${ }^{75}$

Here is not the place to enter into a discussion of the relative value of these analytical approaches; the aim of this section was merely to gain greater conceptual clarity about the options at our disposal when thinking about alternatives to constitutionalism. And as we have seen, the 'institutionalist' variant of pluralism represents less an alternative to than a continuation of constitutionalist themes: even though its different expressions in the literature all focus on diversity and contestation, they see this contestation as contained in a common, constitutional framework. In that, they resemble closely the accommodationist variants of constitutionalism discussed in the previous section, and they are likely to share the latters' problems.

In contrast, systemic pluralism has emerged as a distinct alternative that eschews a common framework in favour of a decentred management of diversity. This differs from constitutionalism, but also from the classical dualist approach that has dominated debates about the relationship between national and international law for long. For dualism was built on the idea that those two legal orders were clearly separate - the domestic order applied inside the state whereas the international order regulated states in their mutual interactions. Pluralism

72 A. Fischer-Lescano \& G. Teubner, Regime-Kollisionen: Zur Fragmentierung des globalen Rechts (Frankfurt am Main: Suhrkamp, 2006).

${ }^{73}$ M. Koskenniemi, 'The Fate of Public International Law: Between Technique and Politics' (2007) 70 Modern Law Review 1, 23.

${ }^{74}$ F. Snyder, 'Governing Economic Globalisation: Global Legal Pluralism and European Law' (1999) 5 European Law Journal 334.

75 B. de Sousa Santos, Toward a New Legal Common Sense (London: Butterworths, 2002); id, 'Beyond neoliberal governance: the World Social Forum as subaltern cosmopolitan politics and legality' in B. de Sousa Santos \& C.A. Rodríguez-Garavito (eds), Law and Globalization from Below (Cambridge: Cambridge University Press, 2005) 29. See also B. Rajagopal, 'Limits of law in counter-hegemonic globalization: the Indian Supreme Court and the Narmada Valley struggle', ibid 183. 
instead responds to the increasing enmeshment of different layers of law and acknowledges that a relationship may be governed by competing rules from a number of them. In this vision, domestic and international law also do not exhaust the range of competing layers - other regionally, personally or functionally defined layers may complement them. Thus while dualism focuses on two separate spheres and their relationship, pluralism deals with interactions among multiple, enmeshed orders.

Pluralism may thus be a distinct concept, but whether it is also normatively appealing is another matter. Most accounts of pluralism in postnational law are of an analytical kind, and even those who highlight its normative virtues typically emphasise the risk of friction it entails. ${ }^{76}$ And from the perspective of most modern political theory, the irregularity of pluralist structures must appear as diametrically opposed to a reasoned, justifiable structure of government. ${ }^{77}$ The risk that pluralism represents no more than a transitional, perhaps (for the time being) inevitable digression from a good order is therefore real. But as I will try to show in the remainder of the paper, seeing systemic pluralism in these terms would downplay the features that make it attractive in a postnational space that, after all, looks very different from the world of the nation-state constitutionalism has so effectively come to inhabit.

\section{PLURALIST VIRTUES}

Most of the interest in pluralism in postnational law has, as I have just mentioned, focused on the analytical aspect rather than the normative case, and much of it has been accompanied by that systems-theoretical sense of inevitability that sees pluralism largely as an unavoidable consequence of the dynamics of society. ${ }^{78}$ Yet once beyond that sentiment, the literature offers three main strands of normative arguments for pluralism (or intimations thereof). One highlights the capacity for adaptation, the second the space for contestation pluralism provides, the third its usefulness for building checks and balances into the postnational order. All three strands capture important aspects of pluralism's appeal, but as will become clear, they are ultimately insufficient to ground a pluralist order in and of themselves.

\section{AdAPTAtion}

As any order based on law, constitutionalism is in a constant tension with changing social circumstances. Whatever view one holds on the methods of constitutional interpretation, written text, judicial precedent or previous

\footnotetext{
${ }^{76}$ E.g., Poiares Maduro, 'Europe and the constitution', n 70 above.

77 P. Allott, 'Epilogue: Europe and the dream of reason' in Weiler \& Wind, n 70 above, 202-225.

78 See Fischer-Lescano \& Teubner, n 72 above.
} 
constitutional moments will always play an important, sometimes the decisive role. ${ }^{79}$ Whether in a stronger or weaker form, a constitution always ties a polity to its past and thus creates tensions in the present.

Pluralism promises to relax such ties, to allow for adaptation to new circumstances in a more rapid and less formalised way: by leaving the relationships between legal suborders undetermined, it keeps them open to political redefinition over time. Whether or not this is advisable in domestic politics, it certainly has some appeal in the postnational space. Here, social and political relations are much more in flux, ideas about political justice are constantly shifting, and our imagination of what governance arrangements may be feasible keeps changing. This means on the one hand that rules we might formulate today may soon look outdated because of a change of our normative sentiments or an expanded horizon of institutional options. On the other hand, such rules may soon seem anachronistic because of a change in the structure of society. All constitutions are as much expressions of abstract normative values as they are reflections of a particular social structure, and they tend to stabilise and immunise that structure. For example, in the elaboration of a postnational constitution we would currently operate under the constraint that beyond the state social cohesion and communicative structures are such that we have to ground democracy in something else than the classical idea of a relatively unitary postnational 'people' and that we would have to give significant weight to national democratic deliberations in order to legitimise postnational decision-making. This constraint, however, may ease over time, particularly in contexts of strong integration like the European Union ${ }^{80}$, and if this happened it would open up manifold new procedural and institutional possibilities. Exploiting these possibilities would be much easier in an order in which the old structure is not inscribed in institutional settings that defy informal change. Think only of the equality of US states in the Senate: whereas in the late $18^{\text {th }}$ century, population differences among states were small enough to make such a solution allowable, they have now grown to proportions that place the institutional structure under significant strain. Because of the high hurdles for adaptation, though, change is most unlikely to happen. ${ }^{81}$

All constitutional settings, including domestic ones, face this challenge of adaptation, but it is particularly pronounced in the postnational context where, to measure by today's standards, the speed and magnitude of social and institutional change are much greater than in most domestic settings. Freezing particular solutions in constitutional form then risks rendering them soon obsolete or even positively harmful; keeping institutional settings flexible in a pluralist structure may be the better option.

\footnotetext{
${ }^{79}$ This is obvious in originalist approaches, but even for a theory that places as much emphasis on moral theory as Ronald Dworkin's, the dimension of 'fit' with history continues to provide a central anchor; see R. Dworkin, Law's Empire (Cambridge, Mass.: Harvard University Press, 1986).

${ }^{80}$ For one vision of such a trajectory, see Habermas, n 18 above.

${ }^{81}$ Pildes, $\mathrm{n} 41$ above, 174.
} 
Such an argument may gain particular force because of the divided character of postnational society. As we have seen above, most constitutionalist responses to this fact involve institutional structures that accommodate but thereby also stabilise societal divides. This is most pronounced in consociationalist settings where rights that attach to particular groups are likely to reinforce existing group divides and maintain them even if individuals' identities change. ${ }^{82}$ As Richard Pildes has recently emphasised, in divided societies adaptability and dynamism are primary virtues of institutional settlements as they allow for a reflection of changing social circumstances - more than particular institutional provisions at the outset, revisability may help reflect and further social integration over time. ${ }^{83}$ And though he focuses on the (limited) options for adaptation that exist within a constitutional framework, choosing a pluralist setting instead might be a furtherreaching step towards that aim.

Another virtue deriving from adaptability may be a greater capacity for learning. Charles Sabel has repeatedly argued that heterarchical networks and revisable rather than rigid norms facilitate processes of experimentation and mutual learning better than hierarchies with rigid norms. ${ }^{84}$ Because they rely on the engagement and experiences of all actors, they are able to generate sounder insights than hierarchical organisations, and because of the easier revisability they are better able to respond to changes in both circumstances and knowledge. This holds especially when the regulatory landscape is characterised by great diversity and the issues at stake involve significant uncertainty and change at a quick pace. In postnational governance, the former is generally true and the latter in most areas, so pluralist, heterarchical structures may be particularly adequate here.

However, adaptability, transformative capacity and openness to learning have a downside: greater flexibility comes with the risk of a surrender to social forces..$^{85}$ It may be highly beneficial in benign circumstances, when the relevant actors show the required disposition for responding to argument and exchanging experiences and knowledge. Adaptability in the institutional structure may also be desirable when social change goes in the right direction (whichever that may be): then flexible structures will also change for the better rather than hold progress back. But none of this can be taken for granted; when shifts take an adverse direction and actors show less good will, more rigid forms may prove preferable. Pluralism's greater adaptability may thus be a virtue only in certain, potentially quite limited conditions.

\footnotetext{
${ }^{82}$ For a survey of such claims, see McGarry, O’Leary \& Simeon, n 37 above, 71-78.

83 Pildes, n 41 above, 184-201.

${ }^{84}$ See, e.g., C.F. Sabel \& J. Zeitlin, 'Learning from Difference: The New Architecture of Experimentalist Governance in the EU' (2008) 14 European Law Journal 271.

85 See, e.g., the critique by Koskenniemi, n 73 above.
} 


\section{CONTESTATION}

If the argument from adaptation is based on an optimistic view of the social environment and its trajectory, that from contestation starts from a more pessimistic one. It assumes that constitutional frameworks are typically elite products, expressions of power and social hegemony, and that the element of disruption and openness in a pluralist order may provide greater contestatory space for weaker actors. ${ }^{86}$

This argument can take a weak or a strong form. In its weak form, it is based on an appreciation of the current political constraints that attempts at postnational constitutionalisation would face. After all, international politics remains dominated by intergovernmental bargaining in which the pursuit of states' self-interest on the basis of material power plays at least a prominent, perhaps the dominant role. ${ }^{87}$ As a result, current structures follow an unjust distribution of power to an inordinate extent, and efforts at reconceiving them in a constitutional fashion are bound to stabilise and reinforce the inequalities behind them - the re-reading of the United Nations Charter as a constitution is a good example here. 88 But the current distribution of power also limits the options we could imagine to form part of a fresh constitutional settlement, and it certainly limits what we could hope to achieve in such a settlement - it may largely end up in an institutionalisation of the preferences of the dominant actors of the day, as many large-scale attempts at institutionalisation have before. ${ }^{89}$ Even in the European Union, where the intergovernmental mode of operation may have been complemented by broader, transnational and civil-society-oriented politics to a greater extent than elsewhere, large-scale institutional change so far appears to have followed an intergovernmental logic, based on self-interest and power. ${ }^{90}$ An explicit attempt at constitution-making may trigger a shift here, as it has with the establishment of the convention process leading up to the 2004 draft constitutional treaty. But even this convention seems to have operated largely in the shadow of what dominant players could be expected to agree to and thus may not have seriously challenged the intergovernmental mode. ${ }^{91}$ For truly different (and fairer) processes, one might

\footnotetext{
86 Thus the emphasis on subaltern, alternative legalities in de Sousa Santos, Toward a New Legal Common Sense, $\mathrm{n} 75$ above, ch. 3 and 9 .

87 See, e.g., R.O. Keohane, 'Governance in a Partially Globalized World' (2001) 95 American Political Science Review 1.

${ }^{88}$ Fassbender, n 19 above, highlights the critical potential of the constitutional idea, especially as regards the issue of veto powers, but the greater legitimation the unequal structure of the UN would gain from such a move is on balance far weightier.

${ }^{89}$ G.J. Ikenberry, After Victory: Institutions, Strategic Restraint, and the Rebuilding of Order After Major Wars (Princeton: Princeton University Press, 2001).

90 A. Moravcsik, The Choice for Europe: Social Purpose and State Power from Messina to Maastricht (London: UCL Press, 1998).

91 P. Magnette \& K. Nicolaïdis, 'The European Convention: Bargaining in the Shadow of Rhetoric' (2004) 27 West European Politics 381; but see also the different emphasis in the appraisals by J.E. Fossum \& A.J. Menendez, 'The Constitution's Gift? A Deliberative Democratic Analysis of Constitution Making in the European Union' (2005) 11 European Law Journal 380; C. Karlsson, 'Deliberation at the Convention: The Final Verdict' (2008) 14 European Law Journal 604.
} 
have to wait for a more radical transformation of European and global politics. Assuming that alternative forms of power (ideational, communicative) are likely to play a stronger rather than weaker role in the future, seeking a constitution now would only benefit those holding the greatest material power today: it would allow them to 'lock in' their dominant position.

This argument for pluralism, based on the fluidity of the postnational order and the role of material power in it, is powerful, but it is also transitional. Pluralism seems to emerge as an attractive option for times of change when better alternatives cannot be realised. But it continues to lack appeal as a long-term vision of what the global order should look like - it seems constitutionalism still provides the better alternative once postnational politics has become more settled and 'domesticated'.

The strong version of the argument from contestation, however, is of a less transitional nature. In this variant, the contestatory space pluralism opens up will be crucial to any postnational order, not just the current one. This depends on a much more pessimistic appraisal of the prospects of reform in the official institutional setting: it typically starts from the view that tools for counterhegemonic action are necessary in any polity, and that a pluralist legal order would facilitate their exercise. In the argument put forward for example by Boaventura de Sousa Santos, alternative legalities can become central tools for the articulation of subaltern politics against the mainstream forms of global governance sustained by dominant economic and military power. ${ }^{22}$

What distinguishes this approach from the weak version of the argument is the lack of hope to eventually institutionalise a just or legitimate order in a constitutionalist form, and in this it connects with some of the critiques of modern constitutionalism I have sketched above. As we have seen, for James Tully constitutions in multicultural societies are typically expressions of dominant cultures, and he therefore seeks to destabilise processes of constitutionalisation in the modern, foundational way. ${ }^{93}$ This analysis resonates with broader critiques. Constitutionalism's aspiration to establish an impartial framework is questioned also by those who, like Chantal Mouffe, are skeptical about the chances for attaining a neutral consensus in diverse societies more generally. ${ }^{94}$ This does not have to go as far as to deny the possibility of reasoned deliberation and consensus between worldviews altogether, as some postmodernists do. Mouffe's skepticism is grounded in the observation that in practice forms of consensus are typically expressions not of an inclusive process leading to an impartial result, but instead of social mechanisms that favour powerful actors whose dominance is then concealed by the supposed neutrality of broad agreement. And those conditions which political theorists defend to ground impartial consensus favour a particular rationality and abstract so much from the circumstances of the individual (in social

\footnotetext{
${ }^{92}$ Sousa Santos, Toward a New Legal Common Sense, n 75 above, ch. 9; id, 'Beyond neoliberal governance', n 75 above.

93 See text at $\mathrm{n} 34$ above.

${ }^{94}$ C. Mouffe, The Democratic Paradox (London: Verso, 2000, ch. 4).
} 
relations, language, culture) that they can hardly count as truly inclusive..$^{95}$ Mouffe's viewpoint is mirrored, for example, in Ran Hirschl's much more empirically-minded, comparative study of the political origins of recent constitutionalisation and the concomitant emergence of judicial review. ${ }^{96} \mathrm{Hirschl}$ interprets these developments, despite their apparent claim to inclusiveness and impartiality, as attempts by political elites to lock in their privileged position and defend it from challenge; constitutions then come to appear as hegemonic tools. If this is true, one would indeed want to deny them full legitimation and provide space for continuous contestation on a fundamental level - something a pluralist, heterarchical order may indeed be able to do.

The argument from contestation usefully draws attention to the fact that law - including constitutions - is not the product of abstract ideas but that of real, and normally problematic, social and political processes. Whether or not one accepts the argument then comes to depend on one's general views about the degree to which such processes can be transformed. Caution is warranted here: already in domestic politics we will hardly ever find the ideal communicative structures that would render a truly fair consensus possible; constitutions, as a result, typically display some of the features of power politics Hirschl's study identifies. If this holds true in the relatively well-integrated, homogeneous contexts of nation-states, we can expect it to be even more pronounced in the far more divided postnational space in which organised material power (through states) is generally seen to play an even more dominant role. Even if constructivists have rightly pointed to the continued (and perhaps increased) impact of ideas and values and the concomitant influence of arguments in international politics, this need not imply a weakening of power in this context; after all, material power is often enough reflected in, and furthered through, ideas and values. ${ }^{97}$ There is little hope for transcending the predominance of power in the postnational space - neither in the near future nor in the long term, especially if we take the limited success of such attempts in the more benign domestic context as a guide.

In these circumstances, an attempt at constitution-making can appear as simply another hegemonic move. ${ }^{98}$ But it may also give the communicative power of weaker actors a greater role: the powerful may be willing to make concessions in order to gain stronger legitimacy for an order that is overall beneficial to them, and this may help change the political logic of the postnational space to some extent. It may also provide tools that can be mobilised later for a transformation of the structure quite at odds with that intended at the inception; powerful actors

\footnotetext{
95 ibid 92-96.

96 R. Hirschl, Towards Juristocracy: The Origins and Consequences of the New Constitutionalism (Cambridge, Mass.: Harvard University Press, 2004).

97 On links between realist/rationalist and constructivist approaches in world politics, see I. Hurd, After Anarchy: Legitimacy and Power in the United Nations Security Council (Princeton: Princeton University Press, 2007); also T. Risse, “Let's Argue!” Communicative Action in World Politics' (2000) 54 International Organization 1.

98 See Koskenniemi, n 73 above, 19.
} 
may well be trapped in their own argumentative and legal strategies. ${ }^{99}$ This only reflects the always janus-faced character of law as both a tool of the powerful as well as an instrument of resistance ${ }^{100}$; which of them gains the upper hand depends on the environment and the success of mobilisation on either side. Balakrishnan Rajagopal has recently pursued this ambiguity with a focus on legal pluralism, tracing the ways in which the multiplicity of applicable legal orders granted social activists in India space but also meant that successes in one order did not necessarily translate into the others. ${ }^{101}$ Thus a pluralist structure does not, in and of itself, allow for more effective contestation than a constitutionalist one. ${ }^{102}$ Whether it does will depend on the context: the greater the power differential behind a potential constitution, and the more that constitution is likely to reflect it, the greater is the likelihood that a pluralist order will provide more effective tools of contestation and delegitimation than the concessions that might be extracted in a constitutional settlement. On the global level at least, this likelihood would appear to be relatively high.

\section{CHECKS AND BALANCES}

The most common argument for a pluralist order stems from an analogy with checks and balances in domestic constitutions. The most obvious grounding for such an analogy lies in the difficulty of justifying the supremacy of any level of postnational governance over the others: if no level can claim superiority, a constitutionalist order that implies ultimate authority (if only that of the constitution, the common framework) will appear problematic. ${ }^{103}$ In order to respect the competing claims of the different levels, we might instead choose a path that aims not so much at integration but at dissociation: one that keeps an equal distance from the ideals of all of them, that refrains from according full control over decisions - through veto rights or otherwise - to either of the competing collectives. If all constituencies are to have decision-making powers beyond merely being listened to, but shall not be able to dictate or veto a particular decision, then no decision can fully bind them all, and each level has to retain the right to challenge it. The resulting picture of postnational governance would then be one of a constant potential for mutual challenge: of decisions with limited authority that may be contested through diverse channels until some (perhaps provisional) closure might be achieved. It would be a picture of checks and balances that result in a form of systemic pluralism.

\footnotetext{
${ }^{99}$ See Risse, n 97 above, 32-33, on such 'self-entrapment'.

${ }^{100}$ In the context of international law, see N. Krisch, 'International Law in Times of Hegemony: Unequal Power and the Shaping of the International Legal Order' (2005) 16 European Journal of International Law 369.

101 Rajagopal, $\mathrm{n} 75$ above.

102 Cf. Sousa Santos, Toward a New Legal Common Sense, n 75 above, 98, 495.

103 See Maduro, 'Europe and the constitution', n 70 above; Schiff Berman, n 68 above, 1179-196; Halberstam, n 65 above.
} 
The first step in this argument is indeed plausible if we consider the normative grounding of the competing polities. Different collectives subnational, national, regional, or global - have a strong initial case, based on culture, nationalism, cosmopolitanism etc., but they all come with serious deficits as well. Subnational and national constituencies are limited in that they cannot fully respond to the needs and interests of those outsiders that are affected by their decisions or have a claim to be considered, for example for reasons of transboundary justice. ${ }^{104}$ The global polity is not capable of instituting structures of democratic participation nearly as thick and effective as those possible on the national level. It is too far removed from individuals, and intergovernmental negotiations will never come with the deliberative structures necessary for effective public involvement; moreover, as mentioned above, we face serious limits of communication across cultural, linguistic and political boundaries. ${ }^{105}$ Regional levels typically combine the advantages, but also the problems of the lower and higher levels - they are not fully inclusive and their democratic structures are not sufficiently deep. ${ }^{106}$

It might be tempting to see these tensions simply as a reflection of competing approaches in political and democratic theory. For example, a cosmopolitan model would delimit the relevant collectives according to the scope of individuals that are significantly affected by particular issues or decisions; as a result, it would locate the relevant collective on a relatively high level. ${ }^{107}$ Liberal nationalists, however, would emphasise the importance of social ties for the realisation of requirements of justice, and would therefore keep decisions on a lower, largely national level. ${ }^{108}$ More republican-minded theories would seek to balance communal ties with concerns about the effectiveness and inclusiveness of self-government regarding issues of broader reach. ${ }^{109}$ Those theories that regard some form of historical or cultural demos as central to democracy will hardly accept decisions taken beyond the national level. ${ }^{110}$ Others that are primarily concerned about the discursive conditions for democratic decision-making may accept regional but perhaps not global institutions. ${ }^{111}$

This list could easily be extended further, but the details of the various approaches matter less than the broader point that the difficulties in the determination of the right level of governance may boil down to a need to choose between theoretical frameworks. Once this choice is made, one could then proceed to assign particular issues to levels of decision-making and would arrive

\footnotetext{
104 See, e.g., Young, n 22 above, 246-251.

105 See, e.g., Habermas, n 24 above, 137-142.

106 In a similar vein, Halberstam, n 65 above, reconstructs the competing views as deriving from the three values of 'voice, expertise and rights' that create competing authority claims.

107 E.g., Held, n 20, 21 above.

108 E.g., D. Miller, National Responsibility and Global Justice (Oxford: Oxford University Press, 2007).

109 E.g., S. Benhabib, The Rights of Others (Cambridge: Cambridge University Press, 2004) 217-221.

110 E.g., P. Kirchhof, 'Der deutsche Staat im Prozeß der europäischen Integration' in J. Isensee \& P. Kirchhof (eds), Handbuch des Staatsrechts der Bundesrepublik. Deutschland, Vol. VII: Normativität und Schutz der Verfassung - Internationale Beziehungen (Heidelberg: Springer, 1993) 855.

111 E.g., Habermas, n 24 above.
} 
either at a federal-style model such as David Held's, at an intergovernmental one that retains the nation-state as the main anchor of the overall edifice, or at some other coherent structure depending on the particular substantive principle at work. The tensions that seemed to suggest a pluralist order would then appear merely as a result of theoretical indecision.

Yet the solution may not be so easy. I already mentioned Iris Young's view that abstract principles, such as inclusion of all those affected by a decision, are in tension with the actual allegiances of individuals and that any institutional structure has to reflect those countervailing concerns. ${ }^{112}$ This can be redescribed as a tension in the liberal project between two directions of autonomy: one insisting on the individual's right to co-determine whatever decision has an effect on her, the other emphasising the importance for autonomy of the individual's (cultural, social) particularity that should be reflected in the decision-making framework. Here lurks a deeper conflict that in the domestic context long remained inconsequential and only came to the surface once traditional models of politics were called into question; it is, in James Bohman's words, 'the fundamental tension between universality and particularity that is built into the constitutions of modern states'. 113 The modern state was built onto a relative congruence not only between decision-makers and decision-takers, but also on that between a particular social community and the scope of those affected by political decisions. However much this community may have been imagined or (forcibly) constructed ${ }^{114}$, the resulting congruence allowed to construct democratic participation in a coherent, unitary way. Tensions between community allegiances and political structures only became apparent where subnational groups retained or developed a stronger collective consciousness that made them claim self-determination on their own. Federal, sometimes asymmetrical arrangements were the typical, though not always stable institutional response to such claims. ${ }^{115}$

If the tension between the scope of communities and that of affected individuals could be largely contained in the context of the nation-state, in the postnational context the gap is too big for a similar containment to work. The conflicting principles may be formulated differently depending on the theoretical framework one operates in, but however the precise conceptualisation, the tension between them is likely to condition the institutional structure to a significant extent. On many issues, it will prevent singling out one collective as determinative; instead, several levels will have claims with similar degrees of justification, and the structural framework should grant them equal importance. Doing so in forms of co-decision (as in consociationalism) would risk serious blockade in a context such

\footnotetext{
112 Young, n 22 above.

113 Bohman, n 29 above, 29; see also S. Benhabib, 'Reclaiming Universalism: Negotiating Republican SelfDetermination and Cosmopolitan Norms' (2005) 25 The Tanner Lectures on Human Values 113, 132 ('The tension between universal human rights claims and particularistic cultural and national identities is constitutive of democratic legitimacy.')

114 B. Anderson, Imagined Communities: Reflections on the Origin and Spread of Nationalism (London: Verso, 1983); W. Connor, 'Nation-Building or Nation-Destroying?' (1972) 24 World Politics 319.

115 See Tierney, n 33 above; and the discussion above, text at n 37 et seq.
} 
as the postnational where the number of players is high. ${ }^{116}$ The best solution might then be a pluralist one: one that withholds full legitimacy from all of the different levels, does not grant any of them ultimate decision-making capacity and instead establishes equidistance to all of them.

Functionally, such an approach may indeed be close to domestic constitutional checks and balances - in both cases, no single site enjoys ultimate decision-making powers but has to face checks by others that, in some respects, may have equally strong claims to authority. ${ }^{117}$ However, as I have pointed out in the conceptual discussion above, domestic checks and balances are typically part of a structured constitutional framework and operate in a common frame of reference - in our context, they would instead operate between such frameworks, not within one of them. In this way, the checks-and-balances idea is radicalised and taken to the systemic level; it has to be if the equal deficits of the different polities are to be reflected.

\section{PLURALISM AND PUBLIC AUTONOMY}

Checks and balances sound immediately attractive, almost uncontroversial on a background of modern constitutional theory, but the above account leaves open a crucial question: who should be entitled to check whom, and why? To some extent, the response may seem too obvious in the context from which the idea originates, the European Union. Here both the national and the European levels have a strong basis both in abstract normative terms and in social practices as they have developed over the last decades. In this case, it might seem clear that checks and balances between those two polity levels are appropriate, and it might also make the proposition attractive that they should grant each other some 'constitutional tolerance' - that they should refrain from demanding obedience from one another but rather operate on a basis of mutual invitations to cooperate. ${ }^{118}$ A pluralist order might be much more suited to such a vision than a constitutionalist one that comes with hierarchies and obligations to comply with the other's orders.

However, the situation is less clear-cut once we move beyond the European to the global realm. Here too, as I have sketched above, there are good arguments for different levels of decision-making on issues of transboundary concerns, yet what this implies in practice is far less obvious. A multiplicity of different regimes are vying for authority, and their relationship with one another and with regional or state organs is far from settled. Should the UN, the WTO or the Financial Action Task Force be equally entitled to 'tolerance' from states? Are regimes such

\footnotetext{
116 See text at n 45 above.

117 Halberstam, n 65 above.

118 J.H.H. Weiler, 'In defence of the status quo: Europe's constitutional Sonderweg' in Weiler \& Wind, n 70 above, 7 .
} 
as those of the SPS Agreement and the Biosafety Protocol on an equal footing and related to one another only as a matter of tolerance, or are there hierarchies at play? And can states or regional entities only expect tolerance from global bodies or claim more, perhaps an ultimate right to decide? The determination of the relevant collectives and of their link to particular institutions, seemingly easy in the European context, proves to be highly problematic on the global level.

The most obvious solution here would be to go back to the normative arguments discussed in the last section and probe further into how they would apply to those multiple regimes. The conflicting arguments for keeping decisionmaking at lower or higher levels might play out differently for the different regimes, and in some cases mutual tolerance might be called for, in others not. We might think, for example, that if decision-making on the global level is primarily justified by greater inclusion of those affected, a body such as the FATF, with a very limited membership but far-reaching effects on outsiders, hardly deserves deference or respect. ${ }^{119}$ On the other hand, the Kyoto Protocol's climate change regime could be seen to respond to the need for non-exclusive, global solutions for transboundary environmental problems and thus to warrant a high degree of tolerance (and perhaps compliance) from states.

\section{Pluralisms of Choice}

This approach seems fairly straightforward but it is only superficially so. For the method we have used so far, relying as it does on a substantive evaluation of the claims of different regimes or collectives, contrasts starkly with pluralist approaches developed by political theorists for the domestic level, which typically start from some form of choice of the individuals involved. In order to gain a clearer view of the difference, it is worth analysing these domestic theories briefly before we return to the postnational level.

Pluralist theories of the state have typically been grounded in the freedom of association. An early influential strand of this kind was English political pluralism, associated especially with Frederick William Maitland, G.D.H. Cole, John Neville Figgis, and Harold Laski. ${ }^{120}$ For them, a political order based on voluntary associations appeared superior to a state-centred one because it promised individuals greater control of their own affairs. Because they originated in individual choice, such associations were also independent from the state in their basis of legitimacy and possessed non-derived powers. Laski, in some of his works, took this so far as to assert that the state was in effect just another association, with no a priori claim to supremacy and dependent on acceptance by

\footnotetext{
119 On the legitimacy problems of the FATF, see R. Hülsse, 'Even clubs can't do without legitimacy: Why the anti-money laundering blacklist was suspended' (2008) Regulation \& Governance 459.

120 See P.Q. Hirst (ed), The Pluralist Theory of the State (London: Routledge, 1989) 1; D. Nicholls, The Pluralist State: The Political Ideas of J.N. Figgis and his Contemporaries (Basingstoke: Macmillan Press, 2nd ed, 1994); also D. Runciman, Pluralism and the Personality of the State (Cambridge: Cambridge University Press, 1997).
} 
other associations and individuals whenever it sought to act on them. ${ }^{121}$ Yet despite their general emphasis on the importance of associations, most English pluralists, including Laski in his most influential writings, accepted a superior role of the state as a guardian of the system: as a guarantor of the freedom of association, as an enforcer of common norms, and as an arbiter between associations. ${ }^{122}$

These theories thus defend forms of institutional, not systemic, pluralism, but here this fact interests me less than their foundation. As we have seen, protagonists of postnational pluralism have typically determined the relevant collectives on an objective basis, starting from substantive theories of where decision-making power should lie. In contrast, the English pluralists used as a foundation individuals' choices of the associations they want to form part of. Even if these choices might not settle the question entirely (as we have seen, a framework of common norms was still seen as necessary), such an approach is nevertheless of a distinctly more participatory, proceduralist character than its postnational analogues. Contemporary theorists of pluralism in the domestic context, such as Paul Hirst and William Galston, follow this participatory path. ${ }^{123}$

The distinctive character of such an approach is demonstrated in Chandran Kukathas's recent work which develops the idea of freedom of association further and radicalises its institutional implications. ${ }^{124}$ In Kukathas's vision, society is an 'archipelago' of (partly overlapping) associations that coexist both next to each other and on different levels, but not in hierarchical relationships: all depend on negotiations and compromises with the others; none can command; and the basic operational principle is toleration. In this order, the state occupies an elevated place but is confined to an even more minimal role than in the approaches mentioned above. It is supposed to ensure order as an "umpire" between associations, but questions of justice are out of its reach since they are contested among different associations and no neutral ground can be found to adjudicate between them. What is just and right must therefore remain undecided; competing views will seek to broaden their support but cannot be enforced against associations that are unwilling to share them. ${ }^{125}$

In Kukathas's vision, thus, toleration operates between the polities founded upon individuals' allegiances, not between collectives delineated in the abstract. What is more, an abstract delineation would be groundless: there are no overarching principles of justice that would transcend those produced within the

${ }^{121}$ See H.J. Laski, 'Law and the State' in Hirst, ibid 197-227, at 214; also P.Q. Hirst, 'Introduction', ibid 1, at 28 .

122 See Hirst, ibid 28-30; Nicholls, n 120 above, ch. 5; H.J. Laski, 'The Problem of Administrative Areas' in Hirst, $\mathrm{n} 120$ above, 131, at 155.

123 See P.Q. Hirst, Associative Democracy (Cambridge: Polity Press, 1994); W.A. Galston, Liberal Pluralism (Cambridge: Cambridge University Press, 2002) ch. 9.

${ }^{2} 4$ C. Kukathas, The Liberal Archipelago (Oxford: Oxford University Press, 2003). Kukathas bases freedom of association not on autonomy but on freedom of conscience (ibid 36-37); but this difference is of little importance in the present context.

125 ibid ch. 6, and especially 252 ('The state should not be concerned about anything except order or peace.'). 
different islands of the archipelago. Those islands owe each other respect merely because they are forms of individual association, not for any furtherreaching qualities. If associational choices diverge, therefore, the structure will necessarily be pluralist; if they do not, it will not. Here the participatory, association-based logic gains its clearest form; and its implications are not limited to the diverse domestic societies that form the primary focus of Kukathas's work but extend well into the international, postnational spheres. ${ }^{126}$

\section{Public Autonomy and the Scope of the Polity}

One does not have to share all of Kukathas's conclusions, or his libertarian outlook, to see the force of this kind of approach. By insisting on the centrality of individuals' allegiances and choices for the determination of the polity, it relates much more closely than an abstract, objective approach with the emphasis on procedure in most contemporary political theory.

This emphasis has always been characteristic of civic republican approaches that have placed popular sovereignty at the centre of their concern; for them, the (political) 'liberties of the ancients' had to trump, or at least parallel the (private) 'liberties of the moderns'. But also for neo-republicans who reject the 'populist' character of such a recourse to the 'ancients'127, the primary good - nondomination - depends crucially on participatory opportunities for individuals, be they expressed as possibilities for contestation ${ }^{128}$ or the capacity for individuals 'as free and equal citizens to form and change the terms of their common life together'. ${ }^{129}$ Perhaps less naturally, most contemporary liberals share in the emphasis on participation. Thus David Held regards as crucial to liberal democracy the ability for individuals 'to choose freely the conditions of their own association'130, and Jeremy Waldron sees participation as 'the right of rights' that allows for the creation of political structures in the face of substantive disagreement - for Waldron, it is indeed participation all the way down. ${ }^{131}$ And John Rawls, responding to Habermas's charge that his views emphasised abstract rights over the exercise of popular sovereignty, insists that the people's constituent power has long been a cornerstone of liberal constitutional and political (as opposed to merely moral) theories. ${ }^{132}$ Thus, it is mainly for those who remain committed to natural law theories to demote participatory procedures to a secondary role.

If participation and the public autonomy of citizens are such pervasive elements of a political theory, their reach has to extend to all elements of the

\footnotetext{
126 ibid 27-29.

127 See P. Pettit, Republicanism: A Theory of Freedom and Government (Oxford: Oxford University Press, 1997) 7-8.

128 ibid 183-205.

129 Bohman, n 29 above, 45.

130 Held, n 20 above, 145

131 Waldron, Law and Disagreement (Oxford: Oxford University Press, 1996) ch. 11, 13.

132 J. Rawls, 'Political Liberalism: Reply to Habermas' (1995) 92 Journal of Philosophy 132, 165.
} 
framework of a polity. In constitutional settings, this is realised through the idea of a 'dualist' democracy: a comprehensive role for popular sovereignty in the making of a constitution, where it defines all terms of the constitutional settlement, and a more attenuated role in the operation of daily politics within the constitutional frame. ${ }^{133}$ However, if participation is thought to extend to all questions of a constitutional character, it also has to apply to the scope of the polity itself. If individuals are 'to choose freely the conditions of their own association'134, they have to be able to determine with whom to associate. As James Bohman puts it, 'to the extent that borders and jurisdictions set the terms of democratic arrangements, they must be open to democratic deliberation'135 - and, we can add, revision.

Yet applying democracy to itself seems to lead into an infinite regress - in order to determine the scope of the polity, we must already know that scope for otherwise a democratic determination could not take place. This chicken-and-egg problem ${ }^{136}$ did not pose grave difficulties during the era of the nation-state: the determination of the polity seemed self-evident and fixed - democratic politics took place in the national realm, providing the ground for views such as Robert Dahl's that ' $t$ the criteria of the democratic process presupposes [sic] the rightfulness of the unit itself. ${ }^{137}$ The scope of the polity seemed only conceivable as exogenous to the democratic process, as settled prior to its operation, usually through historical events, sometimes a constitution.

This corresponds with the observation that the collective behind democratic self-determination is ever only reflectively constituted, i.e. through the attribution of a later act as a representation of the supposed entity. ${ }^{138}$ Normatively, though, this remains unsatisfactory as it excludes public autonomy from one of the most consequential areas of our political framework, and it can also hardly be presented as necessary to cope with an entirely exceptional problem. For democracy's beginnings are typically marred with similar paradoxes: if we want the rules of democracy to be subject to democratic determination, we end up in an infinite regress. ${ }^{139}$ Yet there are ways out of this problem. Take only the most prominent problem, that of democracy's relationship with rights, such as free speech or equality of the vote. Like the scope of the polity, these are both a precondition for, and in need of definition by, the democratic process. If popular sovereignty is no

\footnotetext{
133 See Ackerman, n 8 above, ch. 1; see also J. Rawls, Political Liberalism (New York: Columbia University Press, 1993) 233

${ }^{134}$ Held, n 20 above, 145.

135 Bohman, n 29 above, 17 .

136 See I. Shapiro \& C. Hacker-Cordón, 'Outer Edges and Inner Edges' in id. (eds), Democracy's Edges (Cambridge: Cambridge University Press, 1999) 1.

137 R.A. Dahl, 'Federalism and the Democratic Process' in J. R. Pennock and J. W. Chapman (eds), NOMOS XXV: Liberal Democracy (New York: New York University Press, 1983) 95, 103 (emphasis omitted).

138 See H. Lindahl, 'Constituent Power and Reflexive Identity: Towards an Ontology of Collective Selfhood' in M. Loughlin \& N. Walker (eds), The Paradox of Constitutionalism: Constituent Power and Constitutional Form (Oxford: Oxford University Press, 2008) 9.

139 H.S. Richardson, Democratic Autonomy (Oxford: Oxford University Press, 2002) 67.
} 
longer conceived as the mere exercise of will by a given collective and therefore depends on qualitative attributes such as rights to count as such, and if rights are no longer just given but require procedural elaboration through democratic action, the two are mutually dependent, but in a circular way. None can be thought independently of the other, both require the other to even come into existence. ${ }^{140}$ This relationship is captured in Habermas's diagnosis of a 'co-originality' of private and public autonomy where neither can be thought as prior to the other. But this holds only insofar as we are concerned with their positive dimension - in order to become positive law, to become institutionalised, the two have to complement each other. In the moral dimension, however, we can theorise the rights individuals have to grant each other and introduce them as presuppositions of an institutionalisation through public autonomy - aware of their imperfection, their need to be reinterpreted in the very processes by which such public autonomy constitutes itself. 141

Democracy's relationship with its preconditions is thus complex, even circular, and this complexity is not limited to the question of the scope of the polity but reaches much farther. There is thus no reason to abandon normative theorising about these preconditions - otherwise, democratic theory would surrender precisely at the point where it is confronted with its most serious challenges. It certainly has refused to do so thus far, and important strands of contemporary political theory have in fact sought to tackle precisely the question of the relevant polity, albeit under a different heading and in the domestic, not the postnational framework. For the interest in the rights of minority groups is, at least in part, about the multiplication and contestation of polities within the state setting. We have already seen some of the implications in Chandran Kukathas's work, but also those theories operating on more classical liberal ground are ultimately concerned with the scope of the polity. Will Kymlicka's influential vision of group rights, for example, does not only focus on the classical individual or collective rights to protect cultural spaces from state intervention, but also takes into view the political rights necessary for the realisation of individual autonomy. ${ }^{142}$ Self-government rights - through distinct group institutions as well as through participation in central decision-making structures of the state - are crucial to this approach. But this is only another way to express the idea that within the state different polities compete. And this idea is taken further by those who call for the recognition of difference beyond the realm of classical minorities - difference on the basis of culture, gender, belief etc. What had classically merely engendered calls for negative individual rights, has now often turned into arguments for political rights - for the acceptance of a multiplicity of publics that need to be related to formal institutions in novel, often still uncharted ways. ${ }^{143}$

140 J. Habermas, Between Facts and Norms (Cambridge, Mass.: MIT Press, 1996) 121-122.

141 ibid ch. 3, especially p. 128; in a similar vein, Rawls, n 132 above, 163-170.

142 Kymlicka, n 43 above.

143 See, e.g., Young, n 22 above, ch. 3, 5. 


\section{From Public Autonomy to Pluralism in Postnational LaW}

We have now established a basis for thinking about the structure of the postnational order, one in which the public autonomy of citizens, not abstract moral considerations, carries the central burden. This emphasis may, as Waldron has noted in a similar context, lead to 'a dissonance between what one takes to be the right choice and what one takes to be the authoritative choice in political decision-making' ${ }^{144}$, but as he points out, this is an unavoidable dissonance in any theory of political authority operating in circumstances of disagreement. ${ }^{145}$ Thus we might think that a state-based, a global constitutionalist, or indeed a pluralist order would be most justified in the light of abstract precepts of morality and political theory, but it is only by observing the practices of public autonomy that we can determine which type of order deserves acceptance. As we will see below, a pluralist order does indeed seem to resonate well with such practices at the present time.

\section{Social Practices}

Identifying practices of public autonomy in the postnational context is not an easy task. In the absence of structured public discourses on what the postnational order should look like (instances one might liken to those of 'constitution-making'), indications of how citizens relate to diverging visions of that order remain vague. And what we know about them is likely to engender some pessimism about the possibility of transnational polities. Even in the (politically closely integrated and socially relatively homogeneous) EU context, people still identify to a much larger extent with their national polity than with a European one. ${ }^{146}$ One might thus share Alexander Wendt's skepticism as to the possibility of transcending national allegiances - and thus socially grounding deeper postnational integration, perhaps a 'world state' - in the foreseeable future. ${ }^{147}$ This certainly casts doubts on visions of global constitutionalism that situate ultimate authority in a however much imagined) global constitution - for this would imply a primacy of the polity framework determined in a global polity which does not correspond, even remotely, with the preferences expressed by citizens.

Yet does this imply a return to the primacy of national polities? It probably would if we were faced with a binary choice: if individuals had to choose between being part of a transnational (global or European) and a national polity, we can safely assume that they would opt for the latter. In the European context, when

\footnotetext{
144 Waldron, n 131 above, 246.

145 ibid.

146 Eurobarometer, n 31 above, 27: only three percent of respondents regarded themselves as Europeans only; another seven percent as Europeans firstly and then citizens of their own country.

147 A. Wendt, 'A comment on Held's cosmopolitanism' in Shapiro \& Hacker-Cordón, n 136 above, 127.
} 
asked to rank their different identifications, citizens rank that with their member state consistently, and by a large margin, higher than that with Europe. However, more than half see themselves not solely as 'nationals' but also as 'Europeans'. ${ }^{148}$ This suggests a multiplication of feelings of belonging among relatively large parts of the population, certainly beyond the elites that are typically thought to be more cosmopolitan-minded. ${ }^{149}$ How deep this runs, and to what degree it might extend beyond Europe, is unclear; comprehensive data on such questions on a worldwide scale is simply lacking. However, anecdotal evidence shows that citizens might be readier to grant global institutions extensive powers than is often assumed. For example, in the US, a 2009 poll found that more than a quarter of respondents supported 'a leading role [for the United Nations] where all countries are required to follow U.N. policies. ${ }^{150}$ In a 2004 poll, 68\% of respondents supported majority decision-making in international economic organisations while only $29 \%$ insisted on a veto power for the US151; other polls suggest that at least one third, and possibly as many as two thirds, of Americans want the US to comply with WTO dispute settlement decisions even when they conflict with domestic policies. ${ }^{152}$ And a 1999 poll found that $73 \%$ of respondents regarded themselves as 'citizens of the world' as well as as citizens of the United States. ${ }^{153}$ Relatively broad acceptance of global decision-making can also be found in worldwide polls. In 2007, between 26 and 78 percent of respondents in sixteen countries (and pluralities or majorities in ten of them) agreed that their country 'should be more willing to make decisions within the United Nations even if this means that [their country] will sometimes have to go along with a policy that is not its first choice'. ${ }^{154}$

We should not read too much into these data, but they do suggest that the nation-state is no longer the sole focus of political loyalties. Instead, they reflect a multiplicity of overlapping, sometimes conflicting identities and loyalties, of varying acceptances of different political structures depending on the issue and the situation at hand. 155 This is closely linked to the diagnosis of a multiplication of 'publics', of structures of communication and identification, both in domestic and

\footnotetext{
148 Eurobarometer, n 31 above, 27: 54 percent of respondents regarded themselves as Europeans and citizens of their own country (though 47 percent as citizens of their own country firstly).

${ }^{149}$ For such a focus on elites, see Wendt, n 147 above, 128-129.

150 Gallup, 'Americans Remain Critical of the United Nations', 13 March 2009, www.gallup.com/ poll/116812/Americans-Remain-Critical-United-Nations.aspx.

${ }^{151}$ Chicago Council on Foreign Relations, 'Global Views 2004: American Public Opinion and Foreign Policy', 42, www.ccfr.org/UserFiles/File/POS_Topline\%20Reports/POS\%202004/US\%20Public\% 20Opinion\%20Global_Views_2004_US.pdf.

152 See the conflicting evidence in Chicago Council, ibid, and that reported in Americans and the World, 'International Trade', www.americans-world.org/digest/global_issues/intertrade/wto.cfm.

153 See the report, Americans and the World, 'Globalization', www.americans-world.org/digest/ global_issues/globalization/values.cfm.

154 WorldPublicOpinion.org, 'World Publics Favor New Powers for the UN', 9 May 2007, http://www.worldpublicopinion.org/pipa/articles/btunitednationsra/355.php?lb=btun\&pnt=355\&nid= \&id $=$.

155 For a similar description, see, e.g., Sandel, n 29 above, 350.
} 
transnational relations. ${ }^{156}$ If we think that such facts matter as part of the practices by which individuals determine the shape and size of their polities, we might indeed regard as most adequate a framework in which ultimate authority is diffused. As Michael Sandel suggests,

[o]nly a regime that disperses sovereignty both upward and downward can combine the power required to rival global market forces with the differentiation required of a public life that hopes to inspire the reflective allegiance of citizens. ${ }^{157}$

In this vein, a pluralist postnational order may well be the best reflection of contemporary social practices - or at least a better reflection of them than either nationalist or global constitutionalist visions.

\section{Public Autonomy}

Social practices alone, however, will be insufficient to ground a normatively satisfactory conception of the postnational order. Throughout the previous sections, and in contrast to the more abstract moral approaches that have so far dominated the debate, I have emphasised participation and public autonomy as crucial elements of such a conception. But 'public autonomy' is not exhausted by a mere expression of attitudes or will by citizens. If we think of public autonomy as an expression of a right to 'self-legislation', the element of will has to be complemented by a specification of the conditions under which it can coincide with everybody else's self-legislation: for it is only conceivable as a consequence of the equal autonomy of all. In a Habermasian interpretation, social practices deserve the attribute 'public autonomy' when they concretise the discursive requirements that allow all to be the authors of the rules they are subject to. As we have seen above in the example of rights, this leads to a circular relationship between social practices and the conditions under which they acquire normative, democratic significance: for the practices have to both satisfy and specify such conditions. Popular sovereignty in this reading

is no longer embodied in a visibly identifiable gathering of autonomous citizens. It pulls back into the, as it were, 'subjectless' forms of communication circulating through forums and legislative bodies. ${ }^{158}$ In the constitution-making acts of a legally binding interpretation of the system of rights, citizens make an originary use of a civic autonomy that thereby constitutes itself in a self-referential manner. ${ }^{159}$

156 Dryzek, n 29 above; Bohman, n 29 above.

157 Sandel, n 29 above, 345.

158 Habermas, n 140 above, 136.

159 ibid 128. 
Social practices therefore constitute exercises of public autonomy when they can be understood as a specification of the idea of 'self-legislation'. For Habermas, public autonomy is typically exercised within an existing polity frame; in fact, the discursive conditions of democracy 'explain the performative meaning of the practice of self-determination on the part of legal consociates who recognize one another as free and equal members of an association they have joined voluntarily. ${ }^{160}$ Yet constructively, there is no need to limit this approach to the discourse within a pre-established association - if, as I have argued above, democracy has to apply to the determination of the polity itself, the reach of public autonomy has to extend to the processes by which an association, or multiple associations, are formed. ${ }^{161}$ Processes pertaining to the scope of a polity would then count as an exercise of public autonomy when they represent a plausible interpretation of what it means, for self-legislating individuals, to order the global political space.

It is at this point that more substantive considerations about the right scope of the polity re-enter the debate. As we have seen in the discussion in Part IV, various theoretical frameworks compete here - cosmopolitan, republican, nationalist, etc. Yet one defining trait of the debate, certainly from a broadly liberal perspective, is the tension between universality and particularity: the tension between an emphasis on inclusiveness of all those affected on the one hand, and an insistence on self-determination by groups with particular commonalities and common goals on the other. There is little ground for prioritising one of these aspects over the other, and as I have shown, this difficulty, and the more general problem of countervailing principles, has led commentators to argue for a pluralist order as a means to accommodate the different claims. ${ }^{162}$

As we now return to the issue from a more procedural vantage point, this competition of plausible approaches suggests that individuals have multiple options when it comes to defining what it would mean, for self-legislating individuals, to order the global political space. Yet any determination of the relevant polity through the social practices of some will always have to give an account of how it takes seriously, on the one hand, the claims of outsiders to be included, and on the other, the claims of groups of insiders to pursue their particular goals through their own structures. If it cannot give an account of how to strike that balance, it will hardly count as an exercise of public autonomy.

\section{Plural Polities}

What kind of order does this suggest after all? As we have seen, social practices pertaining to the structure of the postnational order, reflecting as they do a

\footnotetext{
160 ibid 110.

161 If one sees discursive requirements, as Habermas does, as the necessary implications of communicative practices, a restriction to the national polity seems hardly warranted: even within the nation-state, communication with most others only takes place in a mediated way, so the difference with the postnational realm is largely a gradual one.

162 See text at $n 103$ et seq above.
} 
multiplicity of identities and loyalties, would certainly allow for, and probably favour, an order that disperses ultimate authority, that leaves contests for ultimate authority open - a pluralist order. Such an order would not stand in tension with the idea of self-legislation whose implications for public autonomy I have just sketched. As the discussion above had suggested, a pluralist order might indeed be a way to avoid singling out one level of decision-making over others: it might steer clear from the absolute (and problematic) claims of all polities and bring them into a relationship of checks and balances. ${ }^{163}$ For alternative accounts, a justification in terms of public autonomy is more difficult. This is clearest for global constitutionalist models which, as I have already mentioned, do not resonate well with current social practices. And nationalist models, which are closer to such practices, have problems showing a sufficient orientation towards inclusiveness. They may rightly claim that decision-making in a national framework allows for denser democratic deliberation and thicker forms of solidarity ${ }^{164}$, but this is an argument based on benefits to insiders, and it does not seem to give much weight to the right of outsiders to be self-legislating. This problem should at least caution us not to interpret social practices too easily in nationalist terms.

All this may not be entirely conclusive when it comes to structuring the postnational space - too unstructured, undeliberative, uninclusive are current social practices to live up to the full promise of public autonomy and thus provide for authoritative solutions. Yet I would contend that thinking about the problem in a public autonomy framework is the best available approach, and what I have begun to outline here is one way in which such a framework can be developed in a non-ideal context ${ }^{165}$ - and one way in which it might support an argument in favour of a pluralist structure of postnational law.

This framework should also be able to guide us when it comes to the more concrete shape of such a pluralist order. As I mentioned above, conceptualisations of pluralism in the European Union typically do not (and need not) problematise the question as to what polities (and what institutions) deserve respect - too obviously are these the national and European polities and their respective institutions. Beyond the EU, though, the candidates are many and their credentials often unclear; moreover, the link between polities and institutions will often be tenuous.

Which polities deserve respect and tolerance will then depend, again, on the degree to which they are based on practices of public autonomy: on social practices that concretise the idea of self-legislation. The weight of a collective's claim will follow from the strength of its social grounding, of the participatory

\footnotetext{
163 See text at n 103 et seq above.

164 See Miller, n 108 above.

165 The context is non-ideal because, in the postnational space, public autonomy does not (and probably cannot) find a fully adequate expression. But this does not suggest that the national space, in contrast, provides an ideal context: because of the multiplication of identities and the enmeshment of institutions, it can no longer be disentangled from the postnational - public autonomy can no longer be thought as simply national.
} 
practices that support it as well as the plausibility of its attempt to balance inclusiveness and particularity. And whether an institution deserves respect will result from the links it has with a given polity. An international institution may, for example, derive its powers from national polities and thus benefit from their standing if it is sufficiently controlled by them. Or it may claim to represent a broader, transnational (and necessarily less graspable) polity; if this claim succeeds, will then depend on whether there is actual social support for such a polity and its institutional expression.

In all cases, such support will have to be scrutinised as to its public autonomy credentials: as to its deliberative pedigree as well as to its inclusiveness or the strength of its argument for furthering particular goals. Thus, polities and institutions will not deserve respect if they are based on exclusion, leaving out substantial parts of those affected by its decisions, without providing a compelling justification. Cases such as the OECD negotiating foreign investment rules mainly targeted at outsiders would be the most obvious examples. ${ }^{166}$ On the other hand, where a polity shows a strong mobilisation of deliberative resources or puts forward an effective claim to respect for particular values, it might gain standing vis-à-vis others, and it might endow institutions that represent it with a strong position in the global institutional interplay.

Practically, a claim's effectiveness will hinge on its persuasiveness to other collectives and institutions. For if we take seriously the multiplication of polities and their pluralist, heterarchical character, we will not conceive of any overarching, unifying polity, institution or framework of rules. We will instead lean towards the conflict-of-laws model I have sketched earlier as an example of systemic pluralism ${ }^{167}$ : a model that requires each polity, in an exercise of public autonomy through its institutions, to define the terms on which it interacts with others. Different polities may then come to conflicting terms: as the idea of public autonomy leaves concretisation to social practice, such conflicts are only to be expected. Yet this does not imply an all-out laissez-faire; as we have seen, to gain the attribute of 'public autonomy', social practices have to meet substantial conditions.

The resulting structure of the postnational order is likely to be complex and fluid, constantly subject to readjustment and challenge. Different polities compete for recognition, and different institutions seek to link with them (though not necessarily in exclusive ways) to ground their standing. This pluralist structure might resemble an 'archipelago' 168 and will be hard to navigate, but this difficulty is only a reflection of the undecided, diverse character of postnational society in which a recognition of the need to cooperate coincides with the insistence on local, particular allegiances and values. We have to respect this if we are to take

\footnotetext{
166 See, e.g., J. Salzman, 'Labor Rights, Globalization and Institutions: The Role and Influence of the Organization for Economic Cooperation and Development' (2000) 21 Michigan Journal of International Law $769,805-831$

167 See text at $n 71$ et seq above.

${ }^{168}$ Kukathas, n 124 above.
} 
seriously the idea of individuals as self-legislating equals in the definition of the political framework. Pursuing unity and coherence through clear-cut hierarchies or constitutionalisation would be an imposition on them, however well-meaning or advisable in the abstract.

\section{PLURALISM'S CHALLENGES}

A pluralist order, with all its complexity and institutional openness, may reflect the fragmented shape of today's societies, but it also creates anxieties. It lacks the clarity and coherence we expect from a constitutionalist framework, and it seems to surrender the modern hope of ensuring, through an institutional structure, key values of political order: the rule of law, democracy, social stability and the containment of material power. In this section, I will briefly discuss the particular challenge these present for a pluralist vision. In the space of this paper, I cannot discuss them conclusively: this would require not only deeper theoretical explorations, but also empirical investigations into the ways in which pluralist orders function. Here I can only outline ways of approaching these challenges, mainly by sketching a suitable framework of comparison. As we will see, if this framework is constructed realistically, pluralism is unlikely to fare badly at all.

In order to clarify this, let me return to the challenge of power that I have already touched upon in the discussion of pluralism's capacity to create space for contestation. ${ }^{169}$ Pluralism certainly does not erect an institutional framework that could serve as a bulwark against the exercise of material power in the way constitutionalism, in its ideal form, aspires to. But in order to adequately assess comparative advantages, we should leave idealisations behind and turn to what we can realistically expect from constitutionalist and pluralist models under the circumstances of postnational politics and society, with all their divisions and enormous power differentials between actors. If pluralism cannot save us from the exercise of material power, constitutionalism is also entangled with it: a constitutional order has to be close enough to societal conditions to maintain its relevance, and this often requires painful compromises. Moreover, the more divided and unequal a society is, the greater is the temptation for powerful groups to use legal processes to entrench their position - a constitution may then become an instrument of, rather than a bulwark against, hegemony. In turn, the greater space a pluralist order provides may appear less as an inroad for unrestrained power than as an opportunity for resistance.

A non-idealised vision of constitutionalism also helps us to relativise the challenge for pluralism that stems from concerns about stability and integration. An order as institutionally undefined as a pluralist one obviously can hardly guarantee stability in the same way as a settled, institutionally fixed order sometimes can.

${ }^{169}$ See the discussion at n 86 et seq above. 
Stanley Hoffmann thought that, in any event, '[b]etween the cooperation of existing nations and the breaking of a new one there is no stable middle ground'170, and Carl Schmitt held that the stability of (pluralist) federal unions depended on a high degree of homogeneity. ${ }^{171}$ Now, homogeneity is in short supply in postnational society, but it is also doubtful whether, in conditions of divided societies, constitutionalism offers a more promising alternative. For we have seen in the discussion of strategies to accommodate diversity, constitutional rules are unlikely to succeed if they are not based on sufficient social acceptance of the institutional solutions they entrench. ${ }^{172}$ Thus, in deeply divided societies, stability and integration may not be guaranteed by constitutionalist approaches to any greater extent than by pluralist ones. Even the contrary may be true: for as we have also seen above, pluralism's capacity for adaptation may actually facilitate integration over time better than might be possible in a relatively rigid constitutional framework. ${ }^{173}$ As I have sought to show in an article on the European human rights regime, the stability of a postnational order, with its initially often fragile institutions, can actually benefit from the openness of fundamental questions that pluralism implies. For this openness can reduce the antagonism between crucial actors and pave the way for more pragmatic settlements and incremental change, both of which are key to creating a stable institutional structure over time. ${ }^{174}$

The assessment is more complex when it comes to ensuring the rule of law. Pluralism's openness of legal relationships may be seen to allow for greater arbitrariness and create a lack of legal certainty; the multiplicity of applicable rules may subject the individual to different regulatory regimes, or grant it different sets of rights, and leave undecided which one will ultimately be decisive. ${ }^{175}$ The result might appear close to the 'checkerboard laws' Ronald Dworkin regards as violating the principle of integrity. ${ }^{176}$ Yet integrity is only one value that a legal, institutional order should aspire to, and it may sometimes conflict with others. ${ }^{177}$ Democratic procedures, for example, may lead to incoherent rules; in our case, the multiplicity of competing polities is likely to render this all the more likely. Ideally, decisionmaking processes would respect integrity, but when they do not (as is bound to happen in real life), the value of integrity should not simply trump that of legitimate authority. Moreover, integrity and legal certainty are often enough elusive even in domestic constitutional settings: whenever the law is unsettled, the individual has little ability to know how a dispute will eventually be resolved. The

\footnotetext{
170 S. Hoffmann, 'Obstinate or Obsolete? The Fate of the Nation State and the Case of Western Europe' (1966) 95 Daedalus 862, 910.

${ }^{171}$ Schmitt, $\mathrm{n} 63$ above, 375-379.

${ }^{172}$ See the discussion at $\mathrm{n} 51$ above.

173 See the discussion at $n 79$ et seq above.

174 N. Krisch, 'The Open Architecture of European Human Rights Law' (2008) 71 Modern Law Review 183

175 Baquero Cruz, n 4 above, 414.

176 P. Eleftheriadis, 'Pluralism and Integrity', unpublished manuscript (on file with author). For the general argument on integrity, see Dworkin, n 79 above, ch. 6 and 7.

177 This is conceded by Dworkin himself; ibid 217-219.
} 
decisions of highest courts on contested matters of principle are, after all, rarely predictable on legal grounds. Certainty is then produced less through the rules themselves than through established practices of key institutions - which is no different in a pluralist order in which routine interactions often follow predictable lines. ${ }^{178}$ Moreover, a multiplicity of rules may also benefit the individual. The Kadi case in the EU courts, around the fundamental rights protection against UN sanctions, is a case in point: in a constitutionalist reading, as favoured by the European Court of First Instance, individual rights enjoy only limited protection as the supposed interests of international institutions and global politics take precedence. Yet in the more pluralist interpretation of the European Court of Justice, which rejects the superiority of the UN Charter, this precedence vanishes and fundamental rights, as enshrined in EU law, take centre stage. ${ }^{179}$ Thus, even from an individual's perspective, the legal certainty of a unified, constitutionalist order may not always be the most desirable state of affairs. Predictability of decisions is, after all, only one factor among others in the assessment of an institutional structure.

Another fundamental challenge to pluralism arises from ideals of democracy. While constitutionalism ensures the centrality of 'the people' by granting it authorship of the constitution all public power derives from, in a pluralist order no such clear links exist. Popular influence on politics is not structurally secured, and what is more, participation in the decentred, multiple of sites of governance is likely to be thin and diffused. But then again, it is of little help to compare pluralism with an ideal version of constitutionalism that has scarce hopes of realisation in the postnational, or at least the global, context. For the link between a supposed constitution and 'the people' is bound to be extremely tenuous as participatory procedures are nearly impossible to establish: elections are incompatible with the size of the global polity, and deliberative processes lack the communicative preconditions which alone could make them effective. Yet withdrawing into the comfortable, traditional home of national constitutionalism is not an option either - unless interdependence between countries is radically reduced, domestic democracy's ability to influence processes of governance beyond the state is simply too limited. Moreover, as I have discussed at length in this paper, classical forms of democracy are in tension with the contestated character of the polity. If this causes problems in divided national settings, it is bound to cause even greater ones in the postnational context: there is no longer one 'people' that one could place at the centre of an institutional construction. ${ }^{180}$

\footnotetext{
${ }^{178}$ For an example, see N. Krisch, 'The Pluralism of Global Administrative Law' (2006) 17 European Journal of International Law 247, 256-263.

${ }_{179}$ European Court of First Instance, Judgment of 21 September 2005, T-315/01; European Court of Justice, Judgment of 3 September 2008, C, 402/05 and 415/05. For a reading in terms of constitutionalism and pluralism, see G. de Búrca, 'The EU, the European Court of Justice and the International Legal Order after Kadi' (2009) 51 Harvard International Law Journal, forthcoming (available at http://papers.ssrn.com/sol3/papers.cfm?abstract_id=1321313).

180 But see Benhabib, n 109 above, who upholds the idea of a territorially bounded, central 'demos', even if reinterpreted in a process of iteration.
} 
As a result, national models of democracy face serious difficulties in the postnational sphere, and it is no surprise that much democratic theory today is engaged in developing alternatives.

In this paper, I have begun to delineate some of the implications of public autonomy in a world of multiple, decentred polities, and I have tried to suggest that such public autonomy may best be realised in a pluralist order that does not establish rigid hierarchies but retains fluidity in the constant readjustment of the relations of different polities. Here is not the place to explore this issue further; suffice it to point to the proximity of this approach to two main themes in contemporary democratic theory. The first is the attempt, especially by proponents of deliberative democracy such as Iris Young, John Dryzek or James Bohman, to respond to the multiplication of publics both within and beyond the state framework ${ }^{181}$; I have mentioned this before. The second is the emphasis, among theorists as diverse as Philip Pettit and Pierre Rosanvallon, on contestation as a centerpiece of democracy. ${ }^{182}$ Here the focus shifts from participation prior to decision-making - through electoral and deliberative processes - to later acts of questioning, holding to account and, more broadly, to greater reversibility and reflexivity of decision-making processes.

I cannot here discuss the promise and problems of those approaches or inquire further into how their foundations relate to the largely Habermasian vision of public autonomy I have used as a starting point. Yet it is worth stressing that common to all those visions is an awareness of the need to look to models of democracy that are quite different from those we have become used to - not necessarily because our ideals have changed, but because they have to find a different expression in the changed context of (especially postnational) society. Measuring the democratic prospects of a pluralist order against traditional, nationstate democracy (which probably has always been idealised itself) would thus distort the picture, and it would blind us to the aspects of pluralism that resonate with democratic ideals - challenge, contestation, and a responsiveness to the multiple 'demoi' that characterise postnational society.

\section{CONCLUSION}

In the search for paradigms for the emerging postnational order, pluralism has long been seen as, at best, a fitting description. Normatively, it has been regarded as inferior to constitutionalist models that promise a principled, reasoned framework for a structure of global governance which today appears as accidental, haphazard and driven by material power rather than good argument. In this paper, I have tried to show that this view seriously underestimates pluralism's normative

181 Young, n 22 above; Dryzek, n 29 above; Bohman, n 29 above.

182 Pettit, n 127 above; P. Rosanvallon, Counter-Democracy: Politics in an Age of Distrust (trans. A. Goldhammer, Cambridge: Cambridge University Press, 2008). 
appeal. For not only does a pluralist order have considerable strengths in terms of its adaptability, of the space for contestation it opens up, and of the checks and balances between different polities that it creates by leaving the relationships between legal systems undefined. Pluralism is also closer to foundational ideals of political order - namely public autonomy - than rival approaches: the plural, divided identities, loyalties and allegiances that characterise society today are better reflected in a multiplicity of orders than in an overarching framework that implies ultimate authority.

Connected to the ideal of public autonomy, pluralism is also not the laissezfaire approach it is sometimes thought to be. Instead, polities and institutions gain respect from others only if they reflect a vision of how self-legislating equals might order the postnational political space - if they are grounded in social practices with deliberative pedigree and can make a claim to bring inclusiveness and attention to particularity into a plausible balance. This kind of pluralism does 'pose demands on reality' 183 , yet the demands are not institutionalised in an overarching legal framework, and such an institutional openness naturally creates anxiety regarding stability, the rule of law and the influence of power. But pluralism does not necessarily fare worse in these respects than a constitutionalism realistically constructed. For in the circumstances of postnational society, we should not expect to attain constitutionalism in its ideal form: as in divided domestic societies, the necessary accommodation of diversity is likely to weaken its promise of a reasoned, principled order to a significant extent. After all, constitutionalism, just as pluralism, is heavily conditioned by the society it operates in.

This suggests that in the conceptualisation and construction of the postnational order we should proceed with significant caution. Caution, firstly, as regards the deficits of the competing visions: for in the non-ideal circumstances of postnational society, all attempts at constructing order will have serious weaknesses, and it is of little use to compare them to domestic political orders which often operate in far more benign conditions. Caution, secondly, as regards the transferability of domestic models: for we cannot expect those models to achieve the same goals and further the same values in the postnational as in the domestic context; we have observed here the problems in terms of stability, democracy and the rule of law for a constitutionalism that seriously seeks to accommodate diversity. And caution, thirdly, as regards the prospects of institutionalisation: most modern political theory is closely linked to the idea that institutions and law, if rightly designed, are crucial to furthering political justice. In the postnational realm, this is less certain: here, as in other highly unequal settings, institutions may instead largely serve to reflect and entrench the interests and values of particular actors, of particular parts of society.

In this light, pluralism's openness comes to appear as a chance more than as a menace: as a chance to contest, destabilise, deligitimise entrenched power positions - and to pursue progressive causes by other means than constitutional

183 Pace Koskenniemi, n 73 above. 
settlements. This chance comes with a greater burden for everyday political action: if the realisation of key values is not left to institutional structures, it depends on continuous engagement and struggle. This implies greater fluidity and also risk: but as we have seen, the hope to eliminate this risk in postnational society is in any case slim and fraught with high costs. In the divided, highly contested space of the postnational, ideal solutions are elusive - and pluralism may be the best option we have. 